\title{
METHODS FOR INVESTIGATING TRACE ELEMENT BINDING IN SEDIMENTS
}

\author{
Kathryn L. Linge
}

Curtin Water Quality Research Centre, School of Applied Chemistry, Curtin University, GPO Box U1987, Perth, Australia. E-mail: k.linge@curtin.edu.au

Published in: Critical Reviews in Environmental Science and Technology, Volume 38, Issue

3 May 2008, pages $165-196$

DOI: $10.1080 / 10643380601174780$

\begin{abstract}
Sediments play an important role in maintaining water quality. This review describes methods of investigating element binding in sediments, and assesses the value of each for characterising sediment contamination. Although easy to obtain, data from 'bulk' tests such as fractionation schemes or fitting adsorption isotherms cannot describe binding or phase composition definitively. Modern spectroscopic techniques can investigate the sediment surface on a molecular scale, but are not yet used routinely for sediment analysis. Proper assessment of the implications of sediment contamination normally requires more than one method to be used. Comparing contaminant remobilisation rates to the timescales of environmental factors causing remobilisation is also important.
\end{abstract}




\section{Introduction}

Anthropogenic contamination in the environment is a growing concern. Worldwide, the increasing number of water bodies with elevated concentrations of heavy metals and other toxic elements threaten human health and cause degradation of the surrounding environment. Sediments often play an important role in maintaining water quality by removing contaminants from the water column. However, subsequent contaminant remobilisation from the sediment can keep dissolved concentrations elevated long after the initial source has been removed. The manner in which sediment contamination is treated ultimately depends on the sediment's chemical reactivity. Choosing the most appropriate treatment requires an understanding of how the contaminant binds to the sediment and the conditions under which the contaminant will be released back into the water column.

Sediments are heterogeneous mixtures that include both mineral phases (e.g., Fe oxides, Mn oxides) and detrital organic matter. ${ }^{46}$ Contaminants may bind to these phases by adsorption, precipitation, and coprecipitation ${ }^{4,23}$ and element mobility is controlled by both the binding phase and binding mechanism. Researchers originally presumed that, once retained in the sediment, a contaminant was trapped forever. However, it is now appreciated that contaminants can cycle across the sediment-water interface many times. In general, a contaminant is not fixed permanently and many physical and chemical variables can influence contaminant mobility. This review describes current methods used to investigate element binding in sediments and assesses the information that each method is able to provide. Sediment contamination may be examined from two perspectives, either focussing on how contaminants partition between different sediment phases or the conditions that cause contamination to remobilise back into solution. Proper assessment of the implications of sediment contamination requires investigation of both aspects, as well as consideration of the environmental factors causing remobilisation. 


\section{Factors Affecting Remobilisation from Sediments}

Contaminant remobilisation occurs when altered conditions create a gradient to drive the remobilisation. Common driving gradients are changes in redox potential and $\mathrm{pH}$, often caused by the degradation of organic matter and biological activity. ${ }^{47,48}$ Mimicking such gradients exactly in a laboratory is difficult. The development of driving gradients is controlled by the size and depth of the water body, as well as the surrounding climate. The complexity of trace metal distributions in lake waters and sediments is often attributed to the dynamic nature of lakes, where inputs, mixing and removal processes vary on a variety of time scales. Contaminant remobilisation has been well studied in deep lakes and estuaries. $^{10,25,42,184}$ A predictable sequence of events occurs: temperature stratification develops during summer, isolating the bottom waters from the mixed surface layer and limiting oxygen transport to the sediment. These anoxic conditions can last for weeks, promoting the dissolution of $\mathrm{Fe}$ and $\mathrm{Mn}$ oxides and the precipitation of sulphide minerals. ${ }^{29,65}$ Deep lakes often reach equilibrium. However, in shallow lakes the sequence of driving forces is less predictable. While stratification can develop, often on a diurnal pattern, ${ }^{9,63}$ regular wind events ensure that the lake rarely remains stratified for more than a day. The development of anoxic conditions at the sediment-water interface is therefore less frequent and occurs for a shorter period of time. Obviously the rate of contaminant remobilisation becomes more important in these circumstances.

Sediment resuspension is another process in which remobilisation rates may control release. Waves, currents and dredging can all resuspend the bottom sediments of a lake. Sediment resuspension releases interstitial porewater ${ }^{11,126}$ and may lead to contaminant release from the sediment as well. ${ }^{20,37,93}$ Benthic organisms also facilitate the movements of contaminants into and out of sediment by burrowing, respiration or feeding. ${ }^{18,85,108,128}$

The chemical composition of lakewater can change temporally and spatially and this also 
affects the extent of remobilisation from sediments. Dissolved organic matter (DOM) is generally assumed to increase the solubility of elemental contaminants, either because the element is complexed by the DOM, preventing adsorption, or because DOM competes for sorption sites. ${ }^{124,186}$ However DOM can comprise many varied compounds and determination of the mechanisms involved in reactions between metals and DOM is difficult. ${ }^{77,96,145}$ The microbial degradation of DOM to carbon dioxide will affect the redox potential as the process requires an electron acceptor to complete the reaction. ${ }^{158}$ In well mixed waters, oxygen is the most likely electron acceptor because oxygen reduction releases the largest amount of energy. However, in waters depleted in dissolved oxygen (e.g., in sediments or flooded soils) other electron acceptors are active, usually in a predictable sequence (Table 1). These reactions determine the redox potential of the sediments and affect both ion speciation and redox sensitive minerals. Iron redox cycling and the reductive dissolution of $\mathrm{Fe}$ and $\mathrm{Mn}$ minerals, in particular, is significant in controlling contaminant concentrations in deep lakes. ${ }^{29,144}$ These reactions are often depicted as a one dimensional series but usually occur in a two or three dimensional matrix because sediment heterogeneity produces localised areas where only one or two electron acceptors are present. ${ }^{45,136,189}$

Redox reactions also alter $\mathrm{pH}$. Water $\mathrm{pH}$ can change both naturally and as a result of human activity. Several studies have shown that the $\mathrm{pH}$ of waters with significant biological production fluctuates in response to changes in algal biomass on both diel and seasonal timescales. ${ }^{30,39,100}$ Photosynthesis and respiration cause changes in the dissolved carbon dioxide concentrations of a water body, leading to $\mathrm{pH}$ fluctuations. ${ }^{161} \mathrm{pH}$ changes arising from anthropogenic causes, for example the effect of acid mine drainage, are more dramatic. $^{41}$ Large $\mathrm{pH}$ changes initiate the dissolution of sediment minerals, releasing incorporated contaminants; Fe oxides will dissolve at both low and high $\mathrm{pH}$. Even small $\mathrm{pH}$ changes can affect the extent of adsorption of a solute on a surface. $\mathrm{pH}$ controls the 
protonation of dissolved species and functional groups present on the sediment surface. This is the principal source of variable charge in sediments and so affects the extent of contaminant adsorption. $^{143,153}$

\section{Characterising Contaminant Partitioning in Sediments}

Using total concentrations to measure elemental availability is normally inappropriate because this approach includes the assumption that all phases have equal control of the element and that all phases act identically in different environments. Instead, the sediment phase (or phases) that are involved in elemental binding should be identified. Sediments are complex mixtures of both mineral phases and detrital organic matter and current characterisation techniques often produce ambiguous results. Most often chemical extraction and statistical studies have been used to characterise sediments. These 'bulk' analyses tend to lead to oversimplified interpretations that do not take sediment complexity into account. Sediment complexity also means that experiments using model minerals or phases are unable to mimic the behaviour of real sediments. In recent years, however, numerous spectroscopic techniques have allowed analysis at a molecular level, finally providing direct evidence of surface composition and bonding.

\section{Chemical Extraction}

The most popular method of investigating contaminant partitioning in sediments is by the use of chemical extraction, which is usually employed in one of two ways. A single extraction solution might be applied to a sediment sample in order to mimic a specific set of environmental conditions. ${ }^{101}$ In particular, many solutions have been devised to determine element 'bioavailability', although often the choice of extractant is largely empirical. ${ }^{129,151,173}$ Extractants to measure bioavailability can be devised on a more mechanistic basis, however, such as those containing the gastric and intestinal enzymes of organisms likely to come into contact with the sediment. ${ }^{171,172}$ 
The second application of chemical extractions is to investigate sediment mineralogy and contaminant partitioning and the most popular way of doing this by the use of sequential extraction, or fractionation, schemes. ${ }^{23,44,53,73,116}$ Element partitioning between sediment phases is evaluated by treating the sediment with a series of sequential extracting solutions, each targeting a different phase. Analysing each final extractant quantifies the element concentration associated with each targeted phase. In general the same extraction mechanisms are used in all schemes and include ion exchange, acid and base dissolution, reduction, oxidation, and complexation. Each mechanism affects different sediment phases, although some extractants utilise more than one extracting mechanism. What is actually extracted ultimately depends on which extraction solution is used and the sediment being investigated. Many schemes for metals are based on that devised by Tessier et al., ${ }^{168}$ although trace element partitioning of anions like As can be more successful with a schemes specifically developed for P. ${ }^{22,132,185}$ Table 2 lists a number of extraction solutions that have been used in fractionation schemes. A huge variety of different 'recipes' have been devised to extract the same phase, and this variety is an indication of the impossibility of finding one extractant that is entirely specific for one fraction.

The popularity of fractionation schemes stems from the fact that these schemes are simple, accessible, and seemingly straightforward to interpret. However, this is rarely the case. Chemical extraction is unlikely to be completely selective for only one phase. Results are influenced by both reagent choice and extraction time, ${ }^{23}$ as well as the conditions under which the sediment is manipulated. ${ }^{121}$ As a result, different extraction schemes may give different interpretations of partitioning in the same sediment. ${ }^{14,57,64,89}$ Extracted contaminants can also readsorb onto other phases during the procedure and demonstrating post-extraction readsorption experimentally is difficult. Different approaches have yielded widely varying results. $^{12,56,62,127,167}$ Deionised water or ion exchangeable washes between extractions ${ }^{132}$ or 
determining correction factors using trace element spikes ${ }^{56}$ have attempted to address the issue. However there is no consensus on whether these measures improve data interpretation.

Despite the pitfalls, researchers continue to use fractionation schemes and sometimes without due care. Some researchers argue that optimisation and validation is required every time a fractionation scheme is applied to a new sediment. ${ }^{58,109}$ Testing to see whether repeated extraction is required to extract the entire fraction is also suggested. ${ }^{11,117}$ However, the intrinsic nature of the method means that interpretation of results is always influenced by the fractionation scheme used. If the data are intended solely to indicate differences in sediment behaviour or as a tool to compare different sites this may be unimportant. ${ }^{11,95,149}$ However, in most cases, interpretations from fractionation schemes should be corroborated by other methods. Combining fractionation data with spectroscopic and diffraction techniques has been used to monitor the extraction of crystalline phases ${ }^{34,84}$ or speciation ${ }^{142}$ but does depend on crystalline material being present in the sediment for the former. Such experiments are generally not suited to large numbers of analysis either. Fractionation analysis is enhanced by measuring major elements like $\mathrm{Fe}, \mathrm{Al}$, and $\mathrm{Ca}$, which influence dissolution/precipitation and adsorption/desorption equilibria ${ }^{180}$ or comparison to statistical trends in total metal concentrations. ${ }^{95}$

In order to eliminate some variability and to allow standardisation between laboratories, the Community Bureau of Reference (BCR, now EC Standards, Measurements and Testing Programme) devised a three-step fractionation scheme that was tested in interlaboratory trials and applied to a sediment reference material (BCR CRM 601). ${ }^{73,119,174}$ However, even this method has shown variable recoveries for some samples, ${ }^{26,133}$ as well as variability between analysts. ${ }^{27}$ Modifications to the scheme were made to overcome analyst bias and an aqua regia digestion of both the residual and the whole sample was added as a measure of internal consistency. ${ }^{122}$ This has resulted in improved precision and assessment of new reference 
materials continues. ${ }^{87,164}$

\section{Statistical Analysis}

The analysis of statistical relationships between total element concentrations is another 'bulk' method that has been used to identify phase associations. ${ }^{98,130,135}$ The approach is most successful when a single substrate acts as the main binder of a trace element as correlations are less evident when two or more phases influence binding. The technique has been used to both identify general trends in contaminant binding over a large number of different sites ${ }^{98,181}$ and investigate processes in a single waterbody. ${ }^{67,95}$ Statistical relationships have also been used to demonstrate that different mineralogy can exist at related sites. ${ }^{135}$ Whilst the existence of a correlation does not prove that a phase association actually exists, the correlation may augment fractionation information and aid in identification of phases important in binding an element. ${ }^{95}$ As well as using raw data, statistical trends can be investigated after normalization by the concentration of an element such as Al, to account for the dilution effect of minerals that the element does not associate with. ${ }^{95}$ Normalization does require that the coefficient of variation ( $V=$ standard deviation divided by the mean) of the normalising element is similar or better than that of the trace element as otherwise correlation results will be compromised. ${ }^{176}$ Principal component analysis (PCA) is another way of determining the influence of different sediment phases by identifying a set of components that encapsulates the maximum amount of variation in a dataset. ${ }^{130,135}$

Sediment heterogeneity may make assessment of sediment contamination difficult and normalization can be used to account for environmental variation as well. ${ }^{81}$ The enrichment factor $(\mathrm{EF})$ is a method commonly used to determine if element concentrations in sediment are above background. ${ }^{15,79,134,135,188}$ Here, element concentrations are first normalised against the concentration of a representative matrix element, such as $\mathrm{Al}, \mathrm{Li}, \mathrm{Fe}$ and then ratioed to normalised values from a reference sediment. ${ }^{130}$ An EF greater than one may then suggest 
the sediment is contaminated with that element. Investigators must ensure, however, that the normalizing element is not subject to anthropogenic enhancement as well. The resulting EF will also be greatly influenced by the reference point and choosing an appropriate reference sediment is essential. ${ }^{130,188}$

\section{Molecular scale techniques}

Molecular scale techniques have been used to study elemental binding on surfaces since the early 1990s. ${ }^{19,104,110,154}$ In particular X-ray Adsorption Spectroscopy (XAS) techniques such as X-ray Adsorption Fine Structure (EXAFS) and X-ray Adsorption Near-Edge Structure (XANES) can give direct evidence for surface species of oxidation state, number and type of near neighbours, coordination state and bond distance. ${ }^{43,102,113,120,163}$ For a long time, however, these techniques lacked the sensitivity required to analyse contaminant binding in most environmental samples and application was limited to the most contaminated sediments ${ }^{137,142}$ or to characterising adsorption on model phases. ${ }^{43,102,120,163}$ While elemental adsorption has been confirmed on model sediment phases, there is no assurance that these studies actually mimic what is happening in the natural environment. Sorption experiments are usually performed over short timescales and there may be little similarity between the results from such tests and what actually occurs over months or even years in natural sediments. Long term studies of adsorption have demonstrated that sorption can occur in several steps, with rapid surface exchange or adsorption followed by a very slow continuous uptake. ${ }^{2}$ This slower uptake has been interpreted as entrainment of the ion into the solid phase through aging. Thus application of results from short term studies must be applied with caution. Recently detection limits of XAS techniques have improved and more studies of real sediments are now appearing. ${ }^{51,52,114,165}$ However access to facilities providing such techniques is not always available. 


\section{Binding Processes in Sediments}

Sediments bind and release contaminants by one of two basic mechanisms: adsorption/desorption or precipitation/dissolution. However, to properly model partitioning between dissolved and particulate phases in a natural system requires very detailed information that is not always available. ${ }^{99}$ As well as quantifying binding intensities, capacities, and the relative abundance of each important sediment component, the effect of particle coatings and of multi-component aggregation on the binding capacity of each substrate must also be assessed. The kinetics of redistribution among sediment components and the effect of major competitors should also be considered. Quantitative models have been employed to describe adsorption on well defined component surfaces, but such models have seldom been extended to the multicomponent systems typical of nature. Again, the advent of molecular scale techniques does help provide this information, but many experimenters still rely on empirical or macroscopic models and experiments.

\section{Adsorption/Desorption}

Adsorption is a process where a solute in the liquid phase becomes bonded to the surface of a solid, usually on a specific site. Metal adsorption to sediments is analogous to the formation of soluble complexes, with the surface site acting as the 'ligand' in the reaction. ${ }^{32}$ The strength of the bond between the solute and surface site will vary. ${ }^{6}$ Solutes can be weakly bound by non-specific forces (e.g., van der Waals forces) or by electrostatic attraction between a charged solute and the surface site. Solutes are strongly bound by specific adsorption, which occurs when chemical forces of attraction create covalent bonds between the solute and the surface site. Specific adsorption is slower than electrostatic adsorption and is sometimes partly irreversible. The process of adsorption is highly dependent on $\mathrm{pH}, \mathrm{E}_{\mathrm{h}}$, temperature, and the composition of both the solid surface and the solution.

Contaminant sorption onto a solid at equilibrium, $\Gamma\left(\mathrm{mol} \mathrm{g}^{-1}\right)$, can be expressed by the 
equation:

$$
\Gamma=\frac{n^{\text {sed }}}{m^{\text {sed }}}
$$

where $\mathrm{n}^{\text {sed }}$ is the number of moles of a substance $i$ bound per gram of sediment $\left(\mathrm{m}_{\text {sed }}\right)$.

If the equilibrium governing the partitioning of $i$ between the dissolved and solid phases is disturbed, then the change in partitioning can be expressed using a mass balance:

$n_{o}^{\text {sed }}+n_{o}^{\text {wat }}=n_{i}^{\text {sed }}+n_{i}^{\text {wat }}$

where $\mathrm{n}_{o}{ }^{\text {sed }}$ is the number of moles of $i$ sorbed and $\mathrm{n}_{o}{ }^{\text {wat }}$ the number of moles of $i$ dissolved before the disturbance, and $\mathrm{n}_{i}^{\text {sed }}$ and $\mathrm{n}_{i}^{\text {wat }}$ the partitioning of $i$ between the solid and dissolved phase after equilibrium has been reattained. If we express $n^{\text {sed }}$ in terms of $\Gamma, n^{\text {wat }}$ in terms of dissolved concentration, $\mathrm{c}$, and the mass of sediment $\left(\mathrm{m}_{\text {sed }}\right)$ and volume of solution $(\mathrm{v})$ in terms of slurry density $\mathrm{S}=\mathrm{m}_{\text {sed }} / \mathrm{v}$ then:

$$
\Gamma_{o} S+c_{o}=\Gamma_{i} S+c_{i}
$$

This concept has been widely used in experiments where adsorption is measured by adding a solid substrate to a solution of known composition. The amount of $i$ sorbed onto the solid is calculated by measuring concentration changes in the solution. ${ }^{155}$ Most commonly, values of $\Gamma_{i}$ from a series of experiments are plotted against the final equilibrium aqueous concentration attained, $\mathrm{c}_{i}$, producing an adsorption isotherm at a known temperature and pressure. These isotherms have been fitted to an array of empirical models, including Henry's Law, and the Langmuir and Freundlich equations. ${ }^{86,161}$ Henry's law was initially an observational model used for partitioning of volatile substances between liquid and gaseous phases ${ }^{36,86,182}$ and represents a situation where the affinity of the solute to the surface $\left(\mathrm{K}_{H}\right)$ remains constant: 
$\Gamma_{i}=K_{H} c_{i}$

This model is valid at very low concentrations, ${ }^{86}$ but increasing coverage of the surface by solute at higher concentrations usually supresses the sediment's adsorption capacity and the adsorption isotherm is no longer linear.

The Langmuir isotherm was derived using the assumption that adsorption sites on the surface of a solid become occupied by a solute with 1:1 stoichiometry. The isotherm assumes that sorption stops at monolayer coverage and that all sites have the same binding energy, regardless of how much surface has been covered. ${ }^{159}$ The Langmuir equation has proved useful for summarising adsorption isotherm data and has been used extensively to provide modelling input ${ }^{68}$ and is generally written as:

$$
\Gamma_{i}=\frac{a b c_{i}}{1+a c_{i}}
$$

where $a$ is a measure of the site binding strength and $b$ is a measure of the capacity of the surface. ${ }^{178}$ At dilute solutions (i.e., $\mathrm{ac}_{i}<1$ ) the Langmuir equation [5] reduces to the same form as Henry's law [4].

The Freundlich isotherm is based on similar assumptions to the Langmuir isotherm except that the binding energy changes with increasing adsorption, i.e., the bonding strength of available sites is not constant. The equation is actually equivalent to the integral of a continuum of Langmuir equations with a log-normal distribution of Langmuir constants: ${ }^{155,159}$

$$
\Gamma_{i}=A c_{i}^{1 / n}
$$

where $\mathrm{A}$ is a measure of bonding strength, and $\mathrm{n}$ is a measure of surface heterogeneity and always $>1$. The Freundlich equation models solids with heterogeneous surface properties very well over a wide concentration range, ${ }^{159}$ but is inappropriate for $\mathrm{c} \rightarrow 0$ because it does 
not reduce to Henry's law [4].

Many investigators have used the fit of data to particular isotherms to make mechanistic interpretations about metal sorption on surfaces. ${ }^{3,21,38,83,97,169,170}$ However, $\Gamma$ can describe any type of sediment binding and these isotherms fit several different binding mechanisms, including precipitation. ${ }^{31,90,107}$ Conformity to a particular isotherm does not prove that a particular mechanism is operational and sorption models that use macroscopic data are basically curve fitting exercises, useful for summarising and comparing experimental data but not accurately describing the phenomena occurring in the solid-liquid system. ${ }^{59,178}$ Care must be taken when interpreting adsorption/desorption results to elucidate binding mechanisms or when fitting more flexible equations such as the Constant Capacitance model, ${ }^{54}$ the Triple Layer model, ${ }^{182}$ or the Basic Stern model. ${ }^{159}$ These models incorporate so many parameters that almost any given set of data can be made to fit. ${ }^{8,55,82,106,166}$ In some cases the ion adsorption has been correctly described, but using hypothetical surface species that do not necessarily exist. ${ }^{72}$ Dispute also remains over whether variables determined for single ion systems can be used in multi adsorbate systems. ${ }^{49}$ The results of surface complexation models will be improved by using the correct surface structure and number and types of surface sites involved and surface spectroscopy must be used to determine conclusively how a solute is adsorbed. ${ }^{140}$

\section{Precipitation/dissolution}

Precipitation occurs when one or more dissolved species accumulate and form a solid. This process has a Gibbs free energy of reaction, $\Delta \mathrm{G}_{f}^{o}$, expressed as thermodynamic solubility product, $\mathrm{K}_{s p}:{ }^{161}$

$$
\Delta G_{f}^{o}=-R T \ln K_{s p}
$$

where $\mathrm{R}$ is the gas constant $\left(8.314 \mathrm{~J} \mathrm{~K}^{-1} \mathrm{~mol}^{-1}\right)$ and $\mathrm{T}$ is temperature $\left({ }^{\circ} \mathrm{K}\right)$. The solubility 
product for the reaction where the precipitate $\mathrm{A}$ is in equilibrium with dissolved species $\mathrm{B}$ and $\mathrm{C}$ is:

$$
\begin{aligned}
& a A(s) \leftrightarrow b B(a q)+c C(a q) \\
& K_{s p}=\frac{\{B\}^{b}\{C\}^{c}}{\{A\}^{a}}
\end{aligned}
$$

where the \{\} denote species activity. The activity of a pure phase is unity, and in solutions of low ionic strength, the activity of a dissolved species can be approximated by concentration. For illustration, thermodynamic data for some common sediment minerals are given in Table 3.

Similar to $\mathrm{K}_{s p}$ is the ion activity product (IAP), which describes the relationship between the activity (or concentration) of the reactants and products of a reaction at a given time. Comparing the IAP with $\mathrm{K}_{s p}$ is often used to test whether precipitation has occurred. However, this approach is not always valid. Separate trace elements can become included in the crystal structure of precipitating solids, a process known as chemical substitution or coprecipitation. Replacement of a foreign constituent in a crystalline lattice causes decreases in the activity of the solid phase to less than one, therefore decreasing the solubility of the phase. ${ }^{161}$ In many cases the observed occurrence of elements binding to sediments in solutions that appear to be formally unsaturated can be explained by the formation of a solid solution. ${ }^{138,139,141}$ The formation of solid micro-niches within sediment can also occur, regardless of the bulk solution composition. ${ }^{28}$

The converse situation, where IAP that is larger than $\mathrm{K}_{s p}$, does not guarantee precipitation either if the precipitated particles are small (e.g., $<1 \mu \mathrm{m}$ ) or if the supersaturation is too low to overcome the activation energy required to nucleate a new phase. ${ }^{161}$ The rate is also a consideration as precipitation that is thermodynamically favoured can take geological 
timespans to occur. ${ }^{155}$

\section{Differentiating between adsorption/desorption and precipitation/dissolution}

Distinguishing between adsorption and precipitation can be difficult. Adsorption on a surface is inherently two-dimensional, while precipitation produces a three-dimensional solid with thermodynamic properties. ${ }^{155}$ Adsorption is limited by the amount of available surface and generally occurs faster than precipitation. However, both cause a loss of material from solution and the chemical bonds formed in each case can be very similar. ${ }^{156}$

Comparison of typical adsorption/desorption and precipitation/dissolution reactions shows that the equilibrium constant $\left(\mathrm{K}_{\mathrm{s}}\right.$ for adsorption/desorption and $\mathrm{K}_{\mathrm{sp}}$ for precipitation/dissolution) for each has a similar form (Table 4). However, while [S-L], the concentration of ions adsorbed on a surface, depends on the mass of solid present, [SL] is an intrinsic property that is constant if the solid has a constant composition, as illustrated in Figure 1. Therefore one possible approach to conclusively differentiate dissolution from desorption is an analysis of the effect of $\mathrm{S}$ on trace metal remobilisation at fixed $\mathrm{pH}, \mathrm{E}_{\mathrm{h}}$ and temperature. For precipitation/dissolution control, the final solution concentration in a given medium is independent of S. However, if adsorption/desorption controls remobilisation the final solution concentration should vary with $\mathrm{S}$. This method of differentiation is easily applied to natural sediments, but has only had limited application. ${ }^{94}$ The differentiation is made by testing the mass balance equation [3] against the assumption that remobilisation is controlled by adsorption or dissolution.

For dissolution, the final concentration $\mathrm{c}_{i}$ will always be constant, except for very low $\mathrm{S}$ when the amount of solid that is available for dissolution is too small to reach equilibrium concentration. In this case, all of the solid will dissolve. Hence $\mathrm{c}_{i}$ will increase as $\mathrm{S}$ increases to $\mathrm{S}_{\text {sat }}$, at which the constant saturation concentration $\left(\mathrm{c}_{s a t}\right)$ is reached. If $\mathrm{c}_{o}$ is negligible and the amount of soluble mineral per gram of material is $k_{9}$, then: 
$c_{i}=k_{9} S \quad S<S_{s a t}$

$c_{i}=c_{\text {sat }} \quad S \geq S_{\text {sat }}$

To model desorption a suitable isotherm must be chosen to describe the desorption. At trace concentrations, Henry's law [4] applies for equilibrium partitioning, and $\mathrm{K}_{\mathrm{H}}\left(\mathrm{L} \mathrm{g}^{-1}\right)$ may be a summed term if the element is involved in more than one distinct equilibrium. If $\mathrm{c}_{o}$ is negligible, then rearrangement of equations [3] and [4] for the in terms of final equilibrium concentration and slurry density gives:

$c_{i}=\frac{\Gamma_{o} S}{K_{H} S+1}$

More complex equations can be derived for more concentrated solutions using the Langmuir and Freundlich equations. Figure 2 demonstrates the relationship between $\mathrm{c}_{i}$ and $\mathrm{S}$ for different cases of dissolution, described by equation [9], and desorption, described by equation [10]. In some cases, the form of the lines for dissolution and desorption can be very similar and experimental data may be fitted by both. A more incisive test of the suitability of the assumption of desorption versus dissolution is to calculate sets of $\Gamma_{i}, c_{i}$ from the experimental data using equation [3]. Figure 3 shows the resulting plots of $\Gamma_{i}$ versus $\mathrm{c}_{i}$ for the cases presented in Figure 2 and the difference between dissolution and desorption can be seen clearly. Henry's law produces straight line plots with a slope of $\mathrm{K}_{\mathrm{H}}$ (and any curved $\Gamma$-c dependence would indicate any deviation from Henry's Law). For dissolution, $\Gamma_{i}$ must remain near zero until $\mathrm{c}_{\mathrm{sat}}$ is reached. This method has been used to examine As remobilisation from the sediment of a shallow lake. ${ }^{93-95}$ Combined with other rate and adsorption studies, the protocol demonstrated that As remobilisation was controlled by the solubility of a thin, nonstoichiometric $\mathrm{FeP}_{\mathrm{x}} \mathrm{FeAs}_{\mathrm{y}}$ oxyhydroxide surface and values of $\Gamma_{i}, \mathrm{c}_{i}$ deviated grossly from the 
line representing Henry's law or any other adsorption isotherm. ${ }^{94}$ This conclusion was further confirmed because As addition systematically decreased remobilisation from the sediment, as expected from the common ion effect on salt solubility. This result diverges from the generally held assumption that As mobility in the environment is controlled by adsorption/desorption, rather than precipitation/dissolution. Arsenic sorption experiments consistently fit 'adsorption' isotherms $\mathrm{s}^{21,38,97,169,170}$ and concentrations are usually undersaturated with respect to most pure As minerals, leading to the assumption that As precipitation cannot control As solubility. ${ }^{97,103}$ In the case described, the data fitted all these common assumptions and therefore the dissolution mechanism would not have been discovered if $\Gamma_{i}, \mathrm{c}_{i}$ had not been plotted.

\section{Characterising Remobilisation Rates}

Contaminant remobilisation is governed by both thermodynamic and kinetic processes. Chemical reactions can take place on timescales ranging from milliseconds to years. ${ }^{153,154}$ Equilibrium studies alone are often inappropriate to simulate conditions in dynamic water bodies and kinetic investigations are necessary to properly understand contaminant release and mobility. The rate of contaminant remobilisation should always be compared with the timescales of remobilisation events.

Like the equilibrium sorption studies previously discussed, most kinetic methods are devised on the macroscopic scale and cannot intrinsically provide the mechanism of contaminant remobilisation. In simple systems, kinetic data can be used to determine the mechanisms by which a reaction proceeds. ${ }^{161}$ However, in heterogeneous systems, reactions may take place in many steps and the resulting rate equation is often too complex to solve experimentally. For most laboratory experiments, mixing rates in the bulk solution are fast and therefore do not influence measurements of reaction rate. ${ }^{7}$ The overall reaction rate will incorporate multiple chemical surface reaction steps and mass transfer, meaning the experiment will 
produce apparent rate laws unless the overall reaction rate is controlled by a single step. ${ }^{1}$ Experimental kinetic data from heterogeneous systems are usually fitted to simple (often empirical) equations, such as those listed in Table 5. These equations have been applied to both adsorption/desorption and precipitation/dissolution and cannot distinguish between the two mechanisms. Apart from the Empirical First order equation, all these equations retain a time dependence, meaning that, strictly, these equations are unable to fit dissolution data one the solution reaches saturation.

Regardless of whether the mechanism is dissolution or desorption, remobilisation must always involve the diffusion of a species from the solid surface to the solution bulk through the Nernst hydrodynamic boundary layer. ${ }^{157,179}$ The thickness of this layer is determined by hydrodynamic factors such as solution stirring. If stirring is vigorous, the boundary layer thins and this step may then no longer influence the measured reaction rate. The rate of transport $\left(\mathrm{j}, \mathrm{mol} \mathrm{s}^{-1}\right)$ obeys Fick's first law:

$$
j=\frac{D A \Delta C}{\delta}
$$

where $\mathrm{D}$ is the ion diffusion constant, A the surface area of the solid, $\delta$ the Nernst layer thickness and $\Delta \mathrm{C}\left(\mathrm{mol} \mathrm{cm}^{-3}\right)$ the concentration difference between the surface and the bulk. For most ions, $\mathrm{D} / \mathrm{\delta} \sim 10^{-2} \mathrm{~cm} \mathrm{~s}^{-1}$ in vigorously stirred solutions at $25{ }^{\circ} \mathrm{C} .{ }^{91,179}$ Comparison of measured rates with the rate estimated by Fick's first law is a good indication of whether transport across the boundary layer is controlling the overall rate. The role of transport is more complicated in porous solids, as mass transport within pores must also be considered. Many of the empirical equations in Table 5 arise from rate control by this step, depending on the complexity, or pore geometry, of the system. A unified treatment of this step has been provided using plots of rate $^{-1}$ versus time. ${ }^{1,153}$ The most simple demonstration of the relevance of 'pore' diffusion to rate analysis in a system is the 'interruption' test. ${ }^{69}$ 
Simple adsorption/desorption reactions are usually fast, unless stereochemical or complex bonding rearrangements are involved. ${ }^{60,61,153}$ Such rearrangement has been described (for desorption or dissolution) as the detachment of an activated species $[\equiv \mathrm{S}],{ }^{70,160-162}$ assuming that only one functional group on the surface is involved. Far from equilibrium (i.e., when back reactions are negligible), the initial reaction rate is:

$\frac{d c}{d t}=k_{12}[\equiv S]$

where $\mathrm{k}_{12}$ is constant, generally dependent on the surface morphology, crystallographic orientation, nature or density of defects, and the presence of impurities in the solid. ${ }^{158}$ Many mineral reactions have been shown to obey equation [12]. ${ }^{71}$ A more general rate equation for dissolution of a crystal is: ${ }^{17,159,161}$

$\frac{d c}{d t}=k_{13}\left(c_{s}-c\right)^{n}$

where $\mathrm{c}_{\mathrm{s}}$ is the crystal solubility, $\mathrm{c}$ the solution concentration, and $\mathrm{k}_{13}$ and $\mathrm{n}$ constants, with $\mathrm{n}$ $=1$ for most crystals (except close to saturation). $\mathrm{c}_{\mathrm{s}}$ depends on both the solid and solution composition, including $\mathrm{pH}$ and any dissolved complexing agents. ${ }^{70,161}$ The constant $\mathrm{k}_{13}$ depends on surface area and will vary if the crystal surface area changes during the reaction. ${ }^{17}$ $\mathrm{k}_{13}$ must also vary when a thin scale layer dissolves completely or when the dissolving phase activity changes continuously (e.g., proportional to the mole fraction of dissolving phase present in a solid solution on the surface). Rate analysis for these last conditions has been uncertain, ${ }^{70}$ however it has recently been demonstrated ${ }^{94}$ that a possible equation is:

$k_{13}=k_{14}(1-F)$

where $\mathrm{F}=\mathrm{c} / \mathrm{c}_{\mathrm{E}}$ is the fraction of solid dissolved at time $\mathrm{t}$, and $\mathrm{c}_{\mathrm{E}}$ is the limiting concentration $\mathrm{c}_{\mathrm{sat}}$. Combined with other data, this rate constant may allow more appropriate modelling of 
thin scale dissolution.

\section{Conclusions}

This review has described techniques commonly used to characterise sediments and trace element binding to sediments. However, readers should keep in mind the implicit assumption that the sediment sample being studied is representative of the field site of interest and has not been chemically altered during sampling, storage or treatment. In any environmental study involving sediment characterisation, it is extremely important that an appropriate sampling scheme is used and that the handling procedures adopted minimise sediment alteration. ${ }^{16,131}$

Although easy to obtain, data from established 'bulk' tests cannot independently provide definitive information regarding contaminant binding or sediment phase composition. Ideally data from modern techniques like XAS, which describe the sediment surface on a molecular scale, should be used in conjunction with macroscopic tests. However, spectroscopic techniques are much less accessible, more expensive, and still may not be sensitive enough for some natural sediments. Despite the inherent drawbacks, chemical fractionation schemes will remain a popular tool for solid phase characterization until surface techniques can be routinely applied. Results from these schemes are useful when comparing different sediments or the behaviour of different elements, even if a definitive interpretation may be elusive. The analysis of statistical relationships between total elemental concentrations can also help identify trends in elemental associations and may help identify which phases are most important in binding an element. Most importantly, an independent analysis serves as a reminder of the complexity of natural sediments and that fractionation data usually gives an oversimplified account of sediment partitioning. Determining the mechanism by which remobilisation occurs can be difficult because traditional methods, such as fitting data to adsorption isotherms or the calculation of IAP, do not conclusively distinguish between 
adsorption/desorption and precipitation/dissolution. However, studies in which sediment slurry density (S) is varied may provide a 'bulk' method that is capable of differentiating between dissolution and desorption. Finally, kinetic studies of remobilisation must not be overlooked and rates of remobilisation should be compared to the rate of processes controlling remobilisation like sediment resuspension and the development of anoxic conditions.

\section{Acknowledgements}

$\mathrm{K}$. Linge would like to thank H. Linge for his encouragement and helpful discussions on rates and thermodynamics. 


\section{References}

1. Aharoni, C. and Sparks D.L., Kinetics of soil chemical reactions - a theoretical treatment, in Rates of Soil Chemical Processes, Sparks, D.L. and Suarez D.L., Eds., Soil Science Society of America Special Publication 27, Madison, 1991.

2. Ainsworth, C.C., Pilon, J.L., Gassman, P.L., and van der Sluys, W.G., Cobalt, cadmium, and lead sorption to hydrous iron oxide: residence time effect, Soil Sci. Soc. Am. J., 58, 1615, 1994.

3. Ajwa, H.A., and Tabatabai, M.A., Metal-induced sulfate adsorption by soils: III. Application of Langmuir equations, Soil Sci., 162, 169, 1997.

4. Allen, H.E., Partitioning of toxic metals in natural water-sediment systems, in Transport and Transformation of Contaminants Near the Sediment Water Interface, DePinto, J.V., Lick, W., and Paul, J.F., Eds., CRC, Boca Raton, 1993.

5. Allen, H.E. and Unger, M.T., Metal-sediment association constants based on selective fractionation, in Chemicals in the Environment, Lisbon 1-3 July 1986, Lester, J.N., Perry, R., and Sterritt, R.M., Eds., Selper, London, 1986.

6. Allard, B., Hakansson, K., and Karlsson, S., The importance of sorption phenomena in relation to trace element speciation and mobility, in Speciation of Metals in Water, Sediment and Soil Systems, Proceedings of an International Workshop, Sunne Oct 1516, Landner, L., Ed., Springer-Verlag, New York, 1986.

7. Amacher, M.C., Methods of obtaining and analyzing kinetic data, in Rates of Soil Chemical Processes, Sparks, D.L. and Suarez D.L., Eds., Soil Science Society of America Special Publication 27, Madison. 1991.

8. Anderson, M., Bauer, C., Hansmann, D., Loux, N., and Stanforth, R., Expectations and limitations for aqueous adsorption chemistry, in Adsorption of Inorganics at the SolidLiquid Interface, Anderson, M.A. and Rubin, A.J., Eds., Ann Arbor Science, Michigan, 1981.

9. Arnold, T.N. and Oldham, C.E., Trace-element contamination of a shallow wetland in Western Australia, Mar. Freshwater Res., 48, 531, 1997.

10. Azcue, J.M., Mudroch, A., Rosa, F., and Hall, G.E.M., Effects of abandoned gold mine tailings on the arsenic concentrations in water and sediments of Jack of Clubs Lake, B.C., Environ. Technol., 15, 669, 1994.

11. Baldwin, D.S., The phosphorus composition of a diverse series of Australian sediments, 
Hydrobiologia, 335, 63, 1996.

12. Belzile, N., Lecomte, P., and Tessier, A., Testing readsorption of trace elements during partial chemical extractions of bottom sediments, Environ. Sci. Technol., 23, 1015, 1989.

13. Berggren, D., Mulder, J., and Westerhof, R., Prolonged leaching of mineral forest soils with dilute $\mathrm{HCl}$ solutions: the solubility of $\mathrm{Al}$ and soil organic matter, Euro. J. Soil Sci., 49, 305, 1998.

14. Bertalan, E., Bartha, A., Ballok, M., and Varga-Barna, Z., The influence of experimental leaching conditions for the determination of the soluble element content of soil and stream sediment samples, Int. J. Environ. Anal. Chem., 82, 771, 2002.

15. Birch, G.F., Robertson, E., Taylor, S.E., and McConchie, D.M., The use of sediments to detect human impact on the fluvial system, Environ. Geol., 39, 1015, 2000.

16. Birch, G.F., Taylor, S.E., and Matthai, C., Small scale spatial and temporal variance in the concentration of heavy metals in aquatic sediments: a review and some new concepts, Environ. Pollut., 113, 357, 2001.

17. Blesa, M.A., Moranod, P.J., and Regazzoni, A.E., Chemical dissolution of metal oxides, CRC, Boca Raton, 1993.

18. Bradshaw, C., Kumblad, L., and Fagrell, A., The use of tracers to evaluate the importance of bioturbation in remobilising contaminants in Baltic sediments, Estuar. Coast. Shelf Sci., 66, 123, 2006.

19. Brown, G.E. and Parks, G.A., Sorption of trace elements on mineral surfaces: modern perspectives from spectroscopic studies, and comments on sorption in the marine environment, Int. Geol. Rev., 43, 963, 2001.

20. Cappuyns, V. and Swennen, R., Kinetics of element release during combined oxidation and $\mathrm{pH}$ (stat) leaching of anoxic river sediments, Appl. Geochem., 20, 1169, 2005.

21. Carpenter, R., Peterson, M.L., and Jahnke, R.A., Sources, sinks and cycling of arsenic in the Puget Sound region, in Estuarine Interactions, Wiley, M., Ed., Academic Press, New York. 1978.

22. Chang, S.C. and Jackson, M.L., Fractionation of soil phosphorous, Soil Sci., 84, 133, 1957.

23. Chao, T.T., Use of partial dissolution techniques in geochemical exploration, $J$. Geochem. Explor., 20, 101, 1984. 
24. Chao, T.T. and Zhou, L., Extraction techniques for selective dissolution of amorphous iron oxides from soils and sediments, Soil Sci. Soc. Am. J., 47, 225, 1983.

25. Crecelius, E.A., The geochemical cycle of arsenic in Lake Washington and its relation to other elements, Limnol. Oceanogr., 20, 441, 1975.

26. Davidson, C.M., Duncan, A.L., Littlejohn, D., Ure, A.M., and Garden, L.M., A critical evaluation of the three-stage BCR sequential extraction procedure to assess the potential mobility and toxicity of heavy metals in industrially-contaminated land, Anal. Chim. Acta, 363, 45, 1998.

27. Davidson, C.M., Ferreira, P.C.S., and Ure, A.M., Some sources of variability in application of the three-stage sequential extraction procedure recommended by BCR to industrially-contaminated soil, Fresen. J. Anal. Chem., 363, 446, 1999.

28. Davison, W., The solubility of iron sulfides in synthetic and natural-waters at ambienttemperature, Aquat. Sci., 53, 309, 1991.

29. Davison, W., Iron and manganese in lakes, Earth-Sci. Rev., 119, 1993.

30. Dawson, J.J.C., Billett, M.F., and Hope, D., Diurnal variations in the carbon chemistry of two acidic peatland streams in north-east Scotland, Freshwater Biol., 46, 1309, 2001.

31. Del Bubba, M., Arias, C.A., and Brix, H., Phosphorus adsorption maximum of sands for use as media in subsurface flow constructed reed beds as measured by the Langmuir isotherm, Water Res., 37, 3390, 2003.

32. DePinto, J.V., Theis, T.L., Young, T.C., and Leach, S.T., Predicting metals partitioning during resuspension events, in Transport and Transformation of Contaminants Near the Sediment Water Interface, DePinto, J.V., Lick, W., and Paul, J.F., Eds., CRC, Boca Raton, 1994.

33. Deurer, R., Förstner, U., and Shmoll, G., Selective chemical extraction of carbonateassociated metals from recent lacustrine sediments, Geochim. Cosmochim. Acta, 42, $425,1978$.

34. Dold, B., Speciation of the most soluble phases in a sequential extraction procedure adapted for geochemical studies of copper sulfide mine waste, J. Geochem. Explor., 80, $55,2003$.

35. Doner, H.E. and Lynn, W.C., Carbonate, halide, sulfate and sulfide minerals in Minerals in Soil Environments, Dixon, J.B. and Weed, S.B., Eds., Soil Science Society of America, Madison, 1989, 279. 
36. Dzombak, D.A. and Morel, F.M.M., Surface Complex Modelling: Hydrous Ferric Oxide, Wiley, New York, 1990.

37. Eggleton, J. and Thomas, K.V., A review of factors affecting the release and bioavailability of contaminants during sediment disturbance events, Environ. Int., 30, 973, 2004.

38. Elkhatib, E.A., Bennet, O.L., and Wright, R.J., Arsenite sorption and desorption in soils, Soil. Sci. Soc. Am. J., 48, 1025, 1984.

39. Eloranta, P., Relations between physical and chemical variables of water quality and phytoplankton in one eutrophic pond, Aqua Fenn., 15, 105, 1985.

40. Emerson, S., Cranston, R.E., and Liss, P.S., Redox species in a reducing fjord: equilibrium and kinetic considerations, Deep-Sea Res., 26A, 859, 1979.

41. Evangelou, V.P. and Zhang, Y.L., A review - pyrite oxidation mechanisms and acidmine drainage prevention, Crit. Rev. Environ. Sci. Technol., 25, 141, 1995.

42. Faye, M.M., and Diamond, M.L., The role of phytoplankton in the removal of arsenic by sedimentation from surface waters, Hydrobiologia, 324, 117, 1996.

43. Fendorf, S., Eick, M.J., Grossl, P., and Sparks, D.L., Arsenate and chromate retention mechanisms on goethite. 1. Surface structure, Environ. Sci. Technol., 31, 315, 1997.

44. Filgueiras, A.V., Lavilla, I., and Bendicho, C., Chemical sequential extraction for metal partitioning in environmental solid samples, J. Environ. Monitor., 4, 823, 2002.

45. Fones, G.R., Davison, W., and Hamilton-Taylor, J., The fine-scale remobilization of metals in the surface sediment of the North-East Atlantic, Cont. Shelf Res., 24, 1485, 2004.

46. Förstner, U., Inorganic sediment chemistry and elemental speciation, in Sediments: Chemistry and Toxicity of In-Place Pollutants, Baudo, R., Giesy, J., and Muntau, H., Eds., Lewis Publishers, Ann Arbor, 1990.

47. Förstner, U., Non-linear release of metals from aquatic sediments, in Biogeodynamics of Pollutants in Soil and Sediments, Salomens, W. and Stigliani, W.M., Eds., SpringerVerlag, Berlin, 247, 1995.

48. Förstner, U., Redox effects on metal release from contaminated sediments - concepts, processes, experiments, prognosis and remediation, in Contaminated Soil '95, van den Brink, W.J., Bosman, R., and Arendt, F., Eds., Kluwer, Dordrecht, 1995.

49. Gao, Y. and Mucci, A., Acid base reactions, phosphate and arsenate complexation, and 
their competitive adsorption at the surface of goethite in $0.7 \mathrm{M} \mathrm{NaCl}$ solution, Geochim. Cosmochim. Acta, 65, 2361, 2001.

50. García-Rodeja, I. and Gil-Sotres, F., Prediction of parameters describing phosphorusdesorption kinetics in soils of Galicia (Northwest Spain), J. Environ. Qual., 26, 1363, 1997.

51. Gault, A.G., Polya, D.A., Charnock, J.M., Islam, F.S., Lloyd, J.R., and Chatterjee, D., Preliminary EXAFS studies of solid phase speciation of As in a West Bengali sediment, Mineral. Mag., 67, 1183, 2003.

52. Gault, A.G., Polya, D.A., Lythgoe, P.R., Farquhar, M.L., Charnock, J.M., and Wogelius, R.A., Arsenic speciation in surface waters and sediments in a contaminated waterway: an IC-ICP-MS and XAS based study, Appl. Geochem., 18, 1387, 2003.

53. Gleyzes, C., Tellier, S., and Astruc, M., Fractionation studies of trace elements in contaminated soils and sediments: a review of sequential extraction procedures, $T R A C$ Trend. Anal. Chem., 21, 451, 2002.

54. Goldberg, S., Chemical modelling of arsenate adsorption on aluminium and iron oxide minerals, Soil Sci. Soc. Am. J., 50, 1154, 1986.

55. Goldberg, S., Reactions of boron with soils, Plant Soil, 193, 35, 1997.

56. Gómez Ariza, J.L., Giráldez, I., Sánchez-Rodas, D., and Morales, E., Metal readsorption and redistribution during the analytical fractionation of trace elements in oxic estuarine sediments, Anal. Chim. Acta, 399, 295, 1999.

57. Gómez Ariza, J.L., Giráldez, I., Sánchez-Rodas, D., and Morales, E., Comparison of the feasibility of three extraction procedures for trace metal partitioning in sediments from south-west Spain, Sci. Total Environ., 246, 271, 2000.

58. Gómez Ariza, J.L., Giráldez, I., Sánchez-Rodas, D., and Morales, E., Metal sequential extraction procedure optimized for heavily polluted and iron oxide rich sediments, Anal. Chim. Acta, 414, 151, 2000.

59. Griffiths, R.A., Sorption and desorption by ideal two-compartment systems: unusual behavior and data interpretation problems, Chemosphere, 55, 443, 2004.

60. Grossl, P., Eick, M., Sparks, D.L., Goldberg, S., and Ainsworth, C.C., Arsenate and chromate retention mechanisms on goethite. 1. Kinetic evaluation using a pressurejump relaxation technique, Environ. Sci. Technol., 31, 321, 1997.

61. Grossl, P.R. and Sparks, D.L., Evaluation of contaminant ion adsorption/desorption on 
goethite using pressure-jump relaxation kinetics, Geoderma, 67, 87, 1995.

62. Gruebel, K.A., Davis, J.A., and Leckie, J.O., The feasibility of using sequential extraction techniques for arsenic and selenium in soils and sediments, Soil Sci. Soc. Am. J., 52, 390, 1988.

63. Gu, R.C., Luck, F.N., and Stefan, H.G., Water quality stratification in shallow wastewater stabilization ponds, Water Resour. Bull., 32, 831, 1996.

64. Hall, G.E.M., and Pelchat, P., Comparability of results obtained by the use of different selective extraction schemes for the determination of element forms in soils, Water Air Soil Pollut., 112, 41, 1999.

65. Hamilton-Taylor, J., Davison, W., and Morfett, K., The biogeochemical cycling of Zn, $\mathrm{Cu}, \mathrm{Fe}, \mathrm{Mn}$ and dissolved organic $\mathrm{C}$ in a seasonally anoxic lake, Limnol. Oceanogr., 41, 408, 1996.

66. Han, F.X. and Banin, A., Selective sequential dissolution techniques for trace metals in arid-zone soils: the carbonate dissolution step, Commun. Soil Sci. Plant Anal., 26, 553, 1995.

67. Harrington, J.M., La Force, M.J., Rember, W.C., Fendorf, S.E., and Rosenzweig, R.F., Phase associations and mobilization of iron and trace elements in Cour d'Alene Lake, Idaho, Environ. Sci. Technol., 32, 650, 1998.

68. Harter R.D., Kinetics of sorption/desorption processes in soil, in Rates of Soil Chemical Processes, Sparks, D.L. and Suarez, D.L., Eds., Soil Science Society of America Special Publication 27, Madison, 1991.

69. Helfferich, F., Ion Exchange, McGraw-Hill, New York, 1962.

70. Hering, J.G., Implications of complexation, sorption and dissolution kinetics for metal transport in soils, in Metal Speciation and Contamination of Soil, Allen, H.E., Huang, C.P., Baily, G.W., and Bowers, A.R., Eds., CRC, Boca Raton, 1995.

71. Hering, J.G. and Stumm, W., Oxidative and reductive dissolution of minerals, Rev. Mineral, 23, 427, 1990.

72. Hiemstra, T. and Van Riemsdijk, W.H., Surface structural ion adsorption modelling of competitive binding of oxyanions by metal (hydr)oxides, J. Colloid Interf. Sci., 210, $182,1999$.

73. Hlavay, J., Prohaska, T., Weisz, M., Wenzel, W.W., and Stingeder, G.J., Determination of trace elements bound to soils and sediment fractions - (IUPAC technical report), 
Pure Appl. Chem., 76, 415, 2004.

74. Huerta-Diaz, M.A., Carignan, R., and Tessier, A., Measurement of trace-metals associated with acid volatile sulfides and pyrite in organic fresh-water sediments, Environ. Sci. Technol., 27, 2367, 1993.

75. Jackson, B.P. and Miller, W.P., Effectiveness of phosphate and hydroxide for desorption of arsenic and selenium species from iron oxides, Soil Sci. Soc. Am. J., 64, $1616,2000$.

76. Jensen, H.S. and Thamdrup, B., Iron-bound phosphorus in marine sediments as measured by bicarbonate-dithionate extraction, Hydrobiologia, 253, 47, 1993.

77. Jin, X., Bailey, G.W., Yu, Y.S., and Lynch, A.T., Kinetics of single and multiple metal ion sorption processes on humic substances, Soil Sci., 161, 509, 1996.

78. Johnston, S.E. and Barnard, W.M., Comparative effectiveness of 14 solutions for extracting arsenic from 4 Western New-York Soils, Soil Sci. Soc. Am. J., 43, 304, 1979.

79. Jonathan, M.P., Ram-Mohan, V., and Srinivasalu, S., Geochemical variations of major and trace elements in recent sediments, off the Gulf of Mannar, the southeast coast of India, Environ. Geol., 45, 466, 2004.

80. Keon, N.E., Swartz, C.H., Brabender, D.H., Harvey, C., and Hemond, H.F., Validation of an arsenic sequential extraction method for evaluating mobility in sediments, Environ. Sci. Technol., 35, 2778, 2001.

81. Kersten, M. and Smedes, F., Normalization procedures for sediment contaminants in spatial and temporal trend monitoring, J. Environ. Monitor., 4, 109, 2002.

82. Koretsky, C., The significance of surface complexation reactions in hydrologic systems: a geochemist's perspective, J. Hydrol., 230, 127, 2000.

83. Korom, S.F., An adsorption isotherm for bromide, Water Resour. Res., 36, 1969, 2000.

84. La Force, M.J. and Fendorf, S., Solid-phase iron characterization during common selective sequential extractions, Soil Sci. Soc. Am. J., 64, 1608, 2000.

85. La Force, M.J., Fendorf, S., Li, G., Schneider, G.M., and Rosenzweig, R.F., A laboratory evaluation of trace element mobility from flooding and nutrient loading of Couer d'Alene River sediments, J. Environ. Qual., 27, 318, 1998.

86. Langmuir, D., The power exchange function: a general model for metal adsorption onto geological materials, in Adsorption from Aqueous Solutions, Tewari, P.H., Ed., Plenum Press, New York, 41, 1981. 
87. Larner, B.L., Seen, A.J., and Townsend, A.T., Comparative study of optimised BCR sequential extraction scheme and acid leaching of elements in the certified reference material NIST 2711, Anal. Chim. Acta, 556, 444, 2006.

88. Lavkulich, L.M. and Wiens, J.H., Comparison of organic matter destruction by hydrogen peroxide and sodium hypochlorite and its effects on selected mineral constituents, Soil Sci. Soc. Am. Proc., 34, 755, 1970.

89. Levy, E.T. and Schlesinger, W.H., A comparison of fractionation methods for forms of phosphorus in soils, Biogeochemistry, 47, 25, 1999.

90. Li, L. and Stanforth, R., Distinguishing adsorption and surface precipitation of phosphate on goethite ( $\alpha-\mathrm{FeOOH})$, J. Colloid Interf. Sci., 230, 12, 2000.

91. Lide, D.R., Ed., Handbook of Chemistry and Physics, 78th ed., CRC, Boca Raton, 1997.

92. Lindsay, W.L. and Vlek, P.L.G., Phosphate minerals, in Minerals in Soil Environments, Dixon, J.B., Weed, S.B., and Dinauer, R.C., Eds., Soil Science Society of America, Madison. 1977.

93. Linge, K.L. and Oldham, C.E., Arsenic remobilization in a shallow lake: The role of sediment resuspension, J. Environ. Qual., 31, 822, 2002.

94. Linge, K.L. and Oldham, C.E., Control mechanisms for dissolved phosphorus and arsenic in a shallow lake, Appl. Geochem., 19, 1377, 2004.

95. Linge, K.L. and Oldham, C.E., Relating arsenic and phosphorus remobilisation to sediment formation mechanisms using fractionation and trends in elemental composition, Mar. Freshwater Res., 55, 525, 2004.

96. Livens, F.R., Chemical-reactions of metals with humic material, Environ. Pollut., 70, $183,1991$.

97. Livesey, N.T. and Huang, P.M., Adsorption of arsenate by soils and its relation to selected chemical properties and anions, Soil Sci., 131, 88, 1981.

98. Luoma, S.N. and Bryan, G.W., A statistical assessment of the form of trace metals in oxidized estuarine sediments employing chemical extractants, Sci. Total Environ., 17, $165,1981$.

99. Luoma, S.N. and Davis, J.A., Requirements for modelling trace metal partitioning in oxidised estuarine sediments, Mar. Chem., 12, 159, 1983.

100. Maberly, S.C., Diel, episodic and seasonal changes in $\mathrm{pH}$ and concentrations of 
inorganic carbon in a productive lake, Freshwater Biol., 35, 579, 1996.

101. Mahoney, J., Langmuir, D., Gosselin, N., and Rowsen, J., Arsenic readily released to pore waters from buried mill tailings, Appl. Geochem., 20, 947, 2005.

102. Manning, B.A., Fendorf, S.E., and Goldberg, S., Surface structures and stability of arsenic(III) on goethite: spectroscopic evidence for inner-sphere complexes, Environ. Sci. Technol., 32, 2383, 1998.

103. Masscheyleyn, P.H., Delaune, R.D., and Patrick Jr., W.H., Arsenic and selenium chemistry as affected by sediment redox potential and pH, J. Environ. Qual., 20, 522, 1991

104. McGuire, G.E., Fuchs, J., Han, P., Kushmerick, J.G., Weiss, P.S., Simko, S.J., Nemanich, R.J., and Chopra, D.R., Surface characterization, Anal. Chem., 71, 373R, 1999.

105. McKeague, J.A., An evaluation of 0.1 M pyrophosphate and pyrophosphate-dithionate in comparison with oxalate as extractants of the accumulation products in podzols and some other soils, Can. J. Soil Sci., 47, 95, 1967.

106. Morel, F.M.M., Westall, J.C., and Yeasted, J.G., Adsorption models: a mathematical analysis in the framework of general equilibrium calculations in Adsorption of Inorganics at the Solid-Liquid Interface, Anderson, M.A. and Rubin, A.J., Eds., Ann Arbor Science, Michigan. 1981.

107. Ni, J.R. and Sun, W.L., Applicability of the Langmuir equation to copper sorption by loess with high carbonate content, Hydrobiologia, 494, 259, 2003.

108. Niedoroda, A.W., Swift, D.J.P., Reed, C.W., and Stull, J.K., Contaminant dispersal on the Palos Verdes continental margin: III. Processes controlling transport, accumulation and re-emergence of DDT-contaminated sediment particles, Sci. Total Environ., 179, $109,1996$.

109. Nirel, P.M.V. and Morel, F.M.M., Pitfalls of sequential extractions, Water Res., 24, $1055,1990$.

110. O'Day, P.A., Molecular environmental geochemistry, Rev. Geophys., 37, 249, 1999.

111. Oldham, C.E. and Lavery, P.S., Porewater nutrient fluxes in a shallow fetch-limited estuary, Marine Ecol.-Prog. Ser., 183, 39, 1999.

112. Olila, O.G., Reddy, K.R., and Harris, W.G., Forms and distribution of inorganic phosphorus in sediments of 2 shallow eutrophic lakes in Florida, Hydrobiologia, 302, 
147, 1995.

113. Parsons, J.G., Aldrich, M.V., and Gardea-Torresdey, J.L., Environmental and biological applications of extended X-ray absorption fine structure (EXAFS) and X-ray absorption near edge structure (XANES) spectroscopies, Appl. Spectrosc. Rev., 37, 187, 2002.

114. Peltier, E.F., Webb, S.M., and Gaillard, J.F., Zinc and lead sequestration in an impacted wetland system, Adv. Environ. Res., 8, 103, 2003.

115. Penn, M.R., Auer, M.T., van Orman, E.L., and Korienek, J.J., Phosphorus diagenesis in lake sediments: investigations using fractionation techniques, Mar. Freshwater Res., 46, 89, 1995.

116. Pickering, W.F., Selective chemical-extraction of soil components and bound metal species, Crit. Rev. Anal. Chem., 12, 233, 1981.

117. Pickering, W.F., Metal ion speciation - soils and sediments (a review), Ore Geol. Rev., 1, 83, 1986.

118. Potts, P.J., Handbook of Rock Analysis, Viridian Publishing, United Kingdom, 2003.

119. Quevauviller, P., Operationally defined extraction procedures for soil and sediment analysis - I. Standardization, TRAC-Trend. Anal. Chem., 17, 289, 1998.

120. Randall, S.R., Sherman, D.M., Ragnarsdottir, K.V., and Collins, C.R., The mechanism of cadmium surface complexation on iron oxyhydroxide minerals, Geochim. Cosmochim. Acta, 63, 2971, 1999.

121. Rapin, F., Tessier, A., Campbell, P.G.C., and Carignan, R., Potential artifacts in the determination of metal partitioning in sediments by a sequential extraction procedure, Environ. Sci. Technol., 20, 836, 1986.

122. Rauret, G., Lopez-Sanchez, J.F., Sahuquillo, A., Rubio, R., Davidson, C., Ure, A., and Quevauviller, P., Improvement of the BCR three step sequential extraction procedure prior to the certification of new sediment and soil reference materials, J. Environ. Monitor., 1, 57, 1999.

123. Raven, C.P., Jain, A., and Loeppert, R.H., Arsenite and arsenate adsorption on ferrihydrite: kinetics, equilibrium, and adsorption envelopes, Environ. Sci. Technol., 32, 344, 1998.

124. Ravichandran, M., Interactions between mercury and dissolved organic matter-a review, Chemosphere, 55, 319, 2004.

125. Recke, M. and Förstner, U., Oxidation increase mobility of toxic metals in dredged 
sledges, in Chemicals in the Environment, Lisbon 1-3 July 1986, Lester, J.N., Perry, R., and Sterrit, R.M., Eds., Selper, London, 1986.

126. Reddy, K.R., Fisher, M.M., and Ivanoff, D., Resuspension and diffusive flux of nitrogen and phosphorus in a hypereutrophic lake, J. Environ. Qual., 25, 363, 1996.

127. Rendell, P.S., Bately, G.E., and Cameron, A.J., Adsorption as a control of metal concentrations in sediment extracts, Environ. Sci. Technol., 14, 314, 1980.

128. Riedel, G.F., Sanders, J.G., and Osman, R.W., The effect of biological and physical disturbances on the transport of arsenic from contaminated estuarine sediments, Estuar. Coast. Shelf Sci., 25, 693, 1987.

129. Rodriguez, R.R., Basta, N.T., Casteel, S.W., Armstrong, F.P., and Ward, D.C., Chemical extraction methods to assess bioavailable arsenic in soil and solid media, $J$. Environ. Qual., 32, 876, 2003.

130. Rubio, B., Nombela, M.A., and Vilas, F., Geochemistry of major and trace elements in sediments of the Ria de Vigo (NW Spain): an assessment of metal pollution, Mar. Pollut. Bull., 40, 968, 2000.

131. Rubio, R. and Ure, A.M., Approaches to sampling and sample pretreatments for metal speciation in soils and sediments, Int. J. Environ. Anal. Chem., 31, 285, 1993.

132. Ruttenberg, K.C., Development of a sequential extraction method for different forms of phosphorus in marine sediments, Limnol. Oceanogr., 37, 1460, 1992.

133. Sahuquillo, A., Lopez-Sanchez, J.F., Rubio, R., Rauret, G., Thomas, R.P., Davidson, C.M., and Ure, A.M., Use of a certified reference material for extractable trace metals to assess sources of uncertainty in the BCR three-stage sequential extraction procedure, Anal. Chim. Acta, 382, 317, 1999.

134. Salomons, W. and Förstner, U., Metals in the Hydrocycle., Springer-Verlag, Berlin, Heilderberg, New York, Tokyo, 349 pp, 1984.

135. Santos, I.R., Silva, E.V., Schaefer, C.E.G.R., Albuquerque, M.R., and Campos, L.S., Heavy metal contamination in coastal sediments and soils near the Brazilian Antarctic Station, King George Island, Mar. Pollut. Bull., 50, 185, 2005.

136. Santschi, P., Höhener, P., Benoit, G., and Buchholtz-ten Brink, M., Chemical processes at the sediment-water interface, Mar. Chem., 30, 269, 1990.

137. Savage, K.S., Tingle, T.N., O’Day, P.A., Waychunas, G.A., and Bird, D.K., Arsenic speciation in pyrite and secondary weathering phases, Mother Lode Gold District, 
Tuolumne County, California, Appl. Geochem., 15, 1219, 2000.

138. Scheidegger, A.M., Lamble, G.M., and Sparks, D.L., Spectroscopic evidence for the formation of mixed-cation hydroxide phases upon metal sorption on clays and aluminium oxides, J. Colloid Interf. Sci., 186, 118, 1997.

139. Scheidegger, A.M. and Sparks, D.L., Kinetics of the formation and the dissolution of nickel surface precipitates on pyrophyllite, Chem. Geol., 132, 157, 1996.

140. Scheidegger, A.M., and Sparks, D.L., A critical assessment of sorption-desorption mechanisms at the soil mineral/water interface, Soil Sci., 161, 813, 1996.

141. Scheidegger, A.M., Strawn, D.G., Lamble, G.M., and Sparks, D.L., The kinetics of mixed Ni-Al hydroxide formation on clay and aluminium oxide minerals: A timeresolved XAFS study Geochim. Cosmochim. Acta, 62, 2233, 1998.

142. Scheinost, A.C., Kretzschmar, R., and Pfister, S., Combining selective sequential extractions, x-ray absorption spectroscopy, and principal component analysis for quantitative zinc speciation in soil, Environ. Sci. Technol., 36, 5021, 2002.

143. Schindler, P.W. and Stumm, W., The surface chemistry of oxides, hydroxides and oxide minerals, in Aquatic Surface Chemistry: Chemical Processes at the ParticleWater Interface, Stumm, W., Ed., Wiley, New York, 1987.

144. Schwertmann, U. and Taylor, R.M., Iron oxides, in Minerals in Soil Environments, Dixon, J.B. and Weed, S.B., Eds., Soil Science Society of America, Madison, 1989, 379-438.

145. Senesi, N. and Loffredo, E., The chemistry of soil organic matter, in Soil Physical Chemistry, 2nd ed., Sparks, D.L., Ed., CRC, Boca Raton, 1999, 239-370.

146. Shanmukhappa, H., Banerjee, D.K., and Krishnamurthy, K., Humic acids, copper and iron in the sediments of Porto Novo, India, in Chemicals in the Environment, Lisbon 13 July 1986, Lester, J.N., Perry, R., and Sterrit, R.M., Eds., Selper, London, 1986.

147. Shuman, L.M., Fractionation method for soil microelements, Soil Sci., 140, 11, 1985.

148. Shuman, L.M. and Hargrove, W.L., Effect of tillage on the distribution of manganese, copper, iron, and zinc in soil fractions, Soil Sci. Soc. Am. J., 49, 1117, 1985.

149. Slavek, J., Wold, J., and Pickering, W.F., Selective extraction of metal ions associated with humic acids, Talanta, 29, 743, 1982.

150. Slotton, D.G. and Reuter, J.E., Heavy metals in intact and resuspended sediments of a California reservoir, with emphasis on potential bioavailability of copper and zinc, 
Mar. Freshwater Res., 46, 257, 1995.

151. Snape, I., Scouller, R.C., Stark, S.C., Stark, J., Riddle, M.J., and Gore, D.B., Characterisation of the dilute $\mathrm{HCl}$ extraction method for the identification of metal contamination in Antarctic marine sediments, Chemosphere, 57, 491, 2004.

152. Span, D. and Gaillard, J.-F., An investigation of a procedure for determining carbonatebound trace metals, Chem. Geol., 56, 135, 1986.

153. Sparks, D.L., Kinetics of metal sorption reactions, in Metal Speciation and Contamination of Soil, Allen, H.E., Huang, C.P., Baily, G.W., and Bowers, A.R., Eds., CRC, Boca Raton, 1995.

154. Sparks, D.L., Elucidating the fundamental chemistry of soils: past and recent achievements and future frontiers, Geoderma, 100, 303, 2001.

155. Sposito, G., The Surface Chemistry of Soils, Oxford University Press, New York, 1984.

156. Sposito, G., Distinguishing adsorption from surface precipitation, in Geochemical Processes at Mineral Interfaces, Davis, J.A. and Hayes, K.F., Eds., American Chemical Society, 1986, 217-228.

157. Sposito, G., Chemical Equilibria and Kinetics in Soils, Oxford University Press, New York, 1994.

158. Stone, A.T. and Morgan, J.J., Reductive dissolution of metal oxides, in Aquatic Surface Chemistry: Chemical Processes at the Particle-Water Interface, Stumm, W., Ed., Wiley, New York, 1987.

159. Stumm, W., Chemistry of the Solid-Water Interface, Wiley, New York, 1992.

160. Stumm, W. and Furrer, G., The dissolution of oxides and aluminium silicates: examples of surface-coordinated-controlled kinetics, in Aquatic Surface Chemistry: Chemical Processes at the Particle-Water Interface, Stumm, W., Ed., Wiley, New York, 1987.

161. Stumm, W. and Morgan, J.J., Aquatic Chemistry, 3rd ed., Wiley, New York, 1996.

162. Stumm, W. and Wieland, E., Dissolution of oxide and silicate minerals: rates depend on surface speciation, in Aquatic Chemical Kinetics: Reaction Rates of Processes in Natural Waters, Stumm, W., Ed., Wiley, New York, 1990, 367-400.

163. Sun, X. and Doner, H.E., Adsorption and oxidation of arsenite on goethite, Soil Sci., 163, 278, 1998.

164. Sutherland, R.A. and Tack, F.M.G., Determination of $\mathrm{Al}, \mathrm{Cu}, \mathrm{Fe}, \mathrm{Mn}, \mathrm{Pb}$ and $\mathrm{Zn}$ in certified reference materials using the optimized BCR sequential extraction procedure, 
Anal. Chim. Acta, 454, 249, 2002.

165. Takahashi, Y., Sakakibara, N., and Nomura, M., Direct determination of the organic extent of tin species in environmental samples by X-ray absorption near-edge structure spectroscopy, Anal. Chem., 76, 4307, 2004.

166. Tao, Z.Y., Chu, T.W., and Li, W.J., On the application of surface complexation models to ionic adsorption, J. Colloid Interf. Sci., 232, 174, 2000.

167. Tessier, A. and Campbell, P.G.C., Partitioning of trace metals in sediments in Metal Speciation: Theory, Analysis and Application, Kramer, J.R. and Allen, H.E., Eds., Lewis Publishers, Chelsea, MI, 1988.

168. Tessier, A., Campbell, P.G.C., and Bisson, M., Sequential extraction procedure for the speciation of particulate trace metals, Anal. Chem., 51, 844, 1979.

169. Thanabalasingam, P. and Pickering, W.F., Arsenic sorption by humic acids, Environ. Pollut. B, 12, 233, 1986.

170. Thanabalasingam, P. and Pickering, W.F., Effect of $\mathrm{pH}$ on interaction between As(III) or As(V) and manganese(IV) oxide, Water Air Soil Pollut., 29, 205, 1986.

171. Turner, A., Henon, D.N., and Dale, J.L.L., Pepsin-digestibility of contaminated estuarine sediments, Estuar. Coast. Shelf Sci., 53, 671, 2001.

172. Turner, A. and Olsen, Y.S., Chemical versus enzymatic digestion of contaminated estuarine sediment: Relative importance of iron and manganese oxides in controlling trace metal bioavailability, Estuar. Coast. Shelf Sci., 51, 717, 2000.

173. Ure, A.M., Single extraction schemes for soil analysis and related applications, Sci. Total Environ., 178, 3, 1996.

174. Ure, A.M., Quevauviller, P., Muntau, H., and Griepink, B., Speciation of heavy-metals in soils and sediments - an account of the improvement and harmonization of extraction techniques undertaken under the auspices of the BCR of the Commission-of-theEuropean-Communities, Int. J. Environ. Anal. Chem., 51, 135, 1993.

175. van der Merwe, L., Kempster, P.L., van Vliet, H.R., and van Staden, J.F., A pHdependent sequential extraction procedure to determine mobilisation and transport of metals in sediments, Water SA, 20, 27, 1994.

176. van der Weijden, C.H., Pitfalls of normalization of marine geochemical data using a common divisor, Mar. Geol., 184, 167, 2002.

177. van Eck, G.T.M., Forms of phosphorus in particulate matter from the Holland 
Diep/Haerinvliet, The Netherlands, Hydrobiologia, 92, 665, 1982.

178. Veith, J.A. and Sposito, G., On the use of the Langmuir equation in the interpretation of adsorption phenomena, Soil Sci. Soc. Am. J., 41, 697, 1977.

179. Vetter, K.J., Electrochemical Kinetics, Theoretical and Experimental Aspects, Academic Press, New York, 1967.

180. Wallmann, K., Kersten, M., Gruber, J., and Förstner, U., Artifacts in the determination of trace metal binding forms in anoxic sediments by sequential extraction, Int. J. Environ. Anal. Chem., 51, 187, 1993.

181. Wang, F. and Chen, J., Relation of sediment characteristics to trace metal concentration: a statistical study, Water. Res., 34, 694, 2000.

182. Weber Jr, W.J., McGinley, P.M., and Katz, L.E., Sorption phenomena in subsurface systems: concepts, models and effects on contaminant fate and transport, Water Res., 25, 499, 1991.

183. Welham, N.J., Malatt, K.A., and Vukcevic, S., The stability of iron phases presently used for disposal from metallurgical systems - a review, Miner. Eng., 13, 911, 2000.

184. Widerlund, A. and Ingri, J., Early diagenesis of arsenic in sediments of the Kalix River Estuary, Northern Sweden, Chem. Geol., 125, 185, 1995.

185. Williams, J.D.H., Syers, J.K., Harris, R.F., and Armstrong, D.E., Fractionation of inorganic phosphate in calcareous lake sediments, Soil. Sci. Soc. Am. Proc., 35, 250, 1971.

186. $\mathrm{Xu}, \mathrm{H} .$, Allard, B., and Grimvall, A., Influence of $\mathrm{pH}$ and organic substance on the adsorption of As(V) on geologic materials, Water Air Soil Pollut., 40, 293, 1988.

187. Yong, R.N., Galvez-Cloutier, R., and Phadungchewit, Y., Selective sequential extraction analysis of heavy-metal retention in soil, Can. Geotech. J., 30, 834, 1993.

188. Zhang, J., Geochemistry of trace metals from Chinese river/estuary systems: an overview, Estuar. Coast. Shelf Sci., 41, 631, 1995.

189. Zhang, H., Davison, W., Mortimer, R.J.G., Krom, M.D., Hayes P.J., and Davies, I.M., Localised remobilization of metals in a marine sediment, Sci. Total Environ., 296, 175, 2002. 


\section{Figure Captions}

Figure 1. Schematic diagram illustrating the difference between dissolution and desorption.

Figure 2. Relationships between final equilibrium concentration $\left(\mathrm{c}_{i}\right)$ and slurry density $(\mathrm{S})$ for cases of both dissolution and desorption. The black line illustrates dissolution using equations [9a] and [9b] with $k_{9}=4 \mu \mathrm{g} \mathrm{g}^{-1}$ and $\mathrm{c}_{\mathrm{sat}}=133.3 \mu \mathrm{g} \mathrm{L}^{-1}$. The grey lines illustrate desorption using Henry's Law and equation [10]. In case A $\Gamma_{o}=4 \mu \mathrm{g} \mathrm{g}^{-1}$ and $\mathrm{K}_{H}=0.03 \mathrm{~L} \mathrm{~g}^{-1}$, in case B $\Gamma_{o}=40 \mu \mathrm{g} \mathrm{g}^{-1}$ and $\mathrm{K}_{H}=0.3 \mathrm{~L} \mathrm{~g}^{-1}$, and in case $\mathrm{C} \Gamma_{o}=400 \mu \mathrm{g} \mathrm{g}^{-1}$ and $\mathrm{K}_{H}=3 \mathrm{~L} \mathrm{~g}^{-1}$. Dissolution and desorption could be experimentally indistinguishable for some cases when a limited amount of soluble solid is present

Figure 3. Relationships between final equilibrium sorption density $\left(\Gamma_{i}\right)$ and solution concentration $\left(\mathrm{c}_{i}\right)$ for cases of both dissolution and desorption. The black line illustrates dissolution using equations [9a] and [9b], while the grey lines illustrate three cases of desorption, all using equation [10]. The parameters used for each case are the same as those in Figure 2. Plots of $\Gamma_{i}$ against $\mathrm{c}_{i}$ can always experimentally distinguish between dissolution and desorption. 
Kathryn L. Linge, Figure 1, Top edge.

\section{Dissolution}
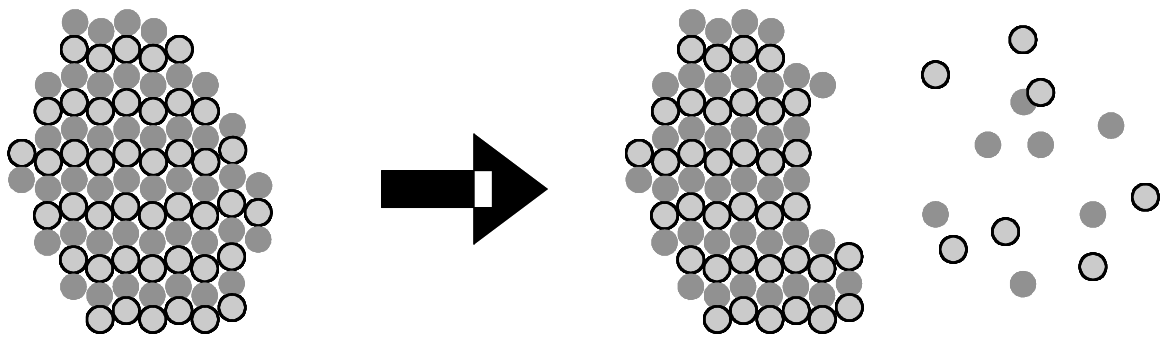

Remobilisation by dissolution is controlled by the activity of the solid

\section{Desorption}
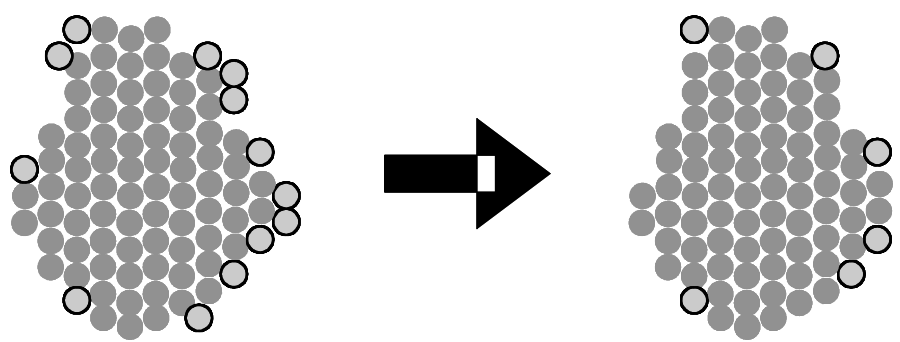

$0 \mathrm{O}$

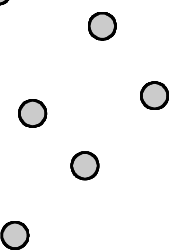

Remobilisation by desorption is proportional to the mass of the solid present 
Kathryn L. Linge, Figure 2, Top edge.

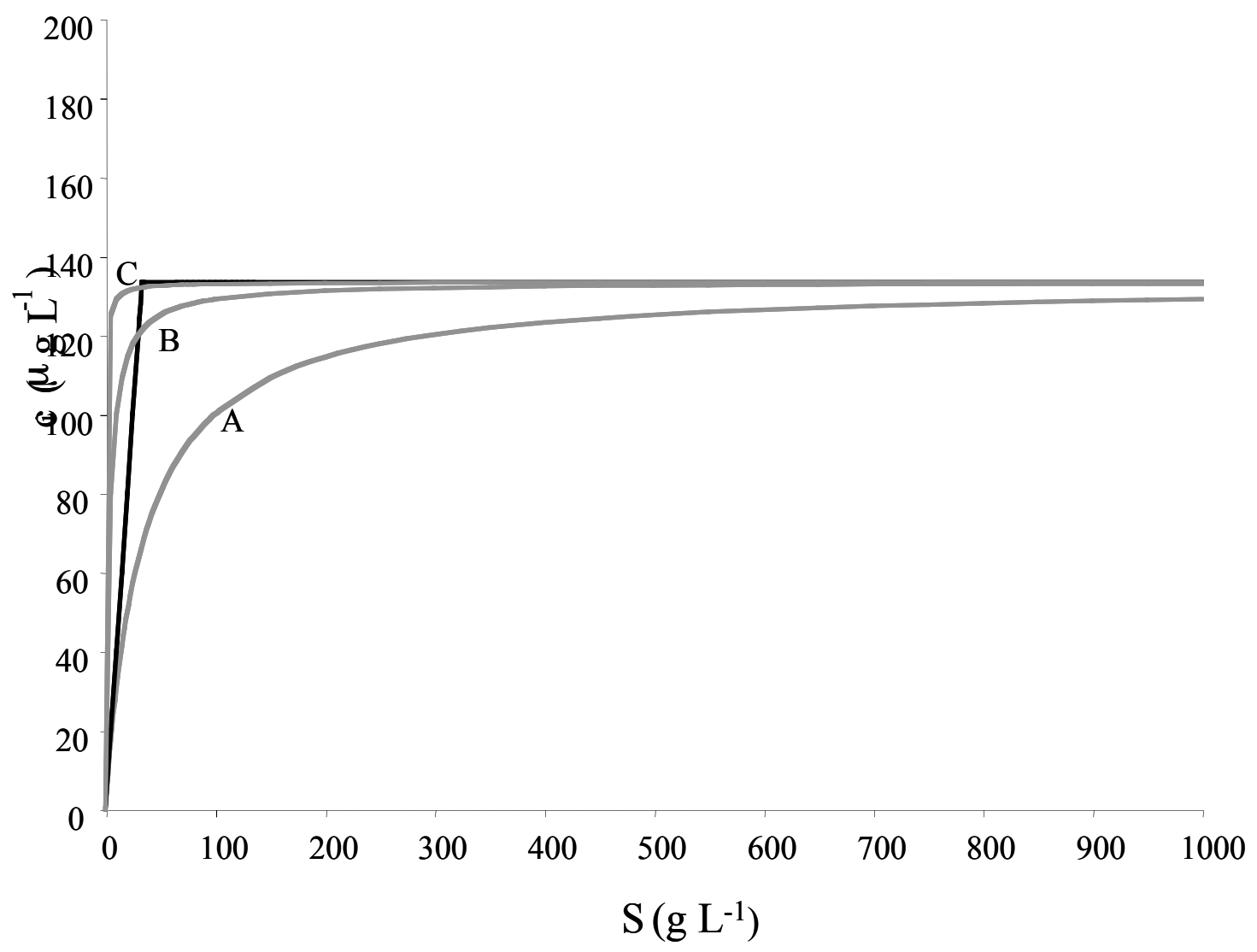


Kathryn L. Linge, Figure 3, Top edge.

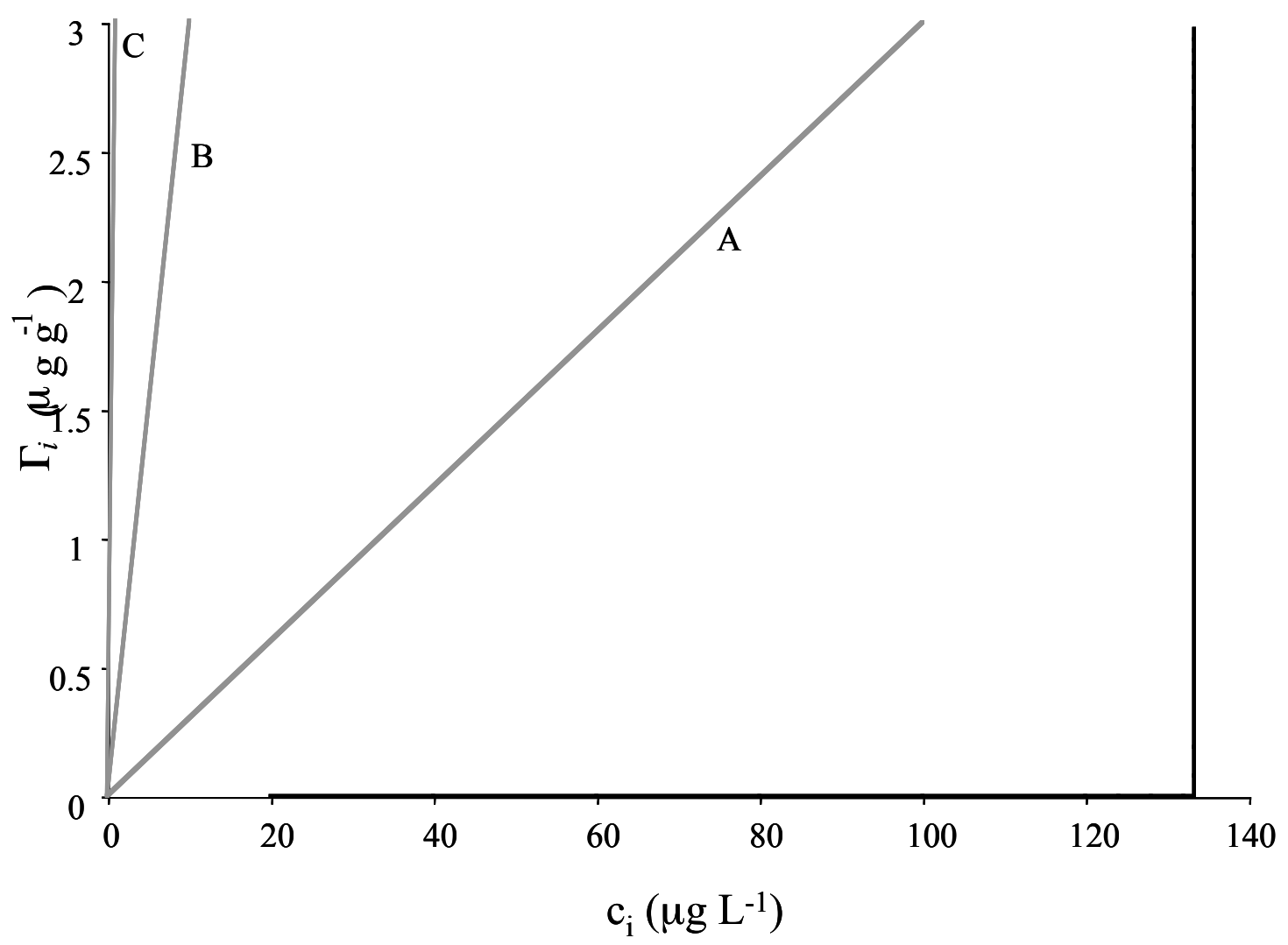




\section{Tables}

Table 1. Redox half reactions for common electron acceptors, adapted from Emerson et al. ${ }^{40}$

\begin{tabular}{lc}
\hline Reaction & $\mathrm{E}_{\mathrm{h}}(\mathrm{mV})^{136}$ \\
\hline $\mathrm{O}_{2}(\mathrm{~g})+4 \mathrm{H}^{+}+4 e^{-} \leftrightarrow 2 \mathrm{H}_{2} \mathrm{O}$ & $0-750$ \\
$\mathrm{NO}_{3}^{-}+6 \mathrm{H}^{+}+5 e^{-} \leftrightarrow 0.5 \mathrm{~N}_{2}(g)+3 \mathrm{H}_{2} \mathrm{O}$ & $0-700$ \\
$\mathrm{MnO}_{2}(\mathrm{~s})+4 \mathrm{H}^{+}+2 e^{-} \leftrightarrow \mathrm{Mn}^{2+}+2 \mathrm{H}_{2} \mathrm{O}$ & $0-450$ \\
$0.5 \mathrm{~N}_{2}+4 \mathrm{H}^{+}+3 e^{-} \leftrightarrow \mathrm{NH}_{4}^{+}$ & \\
$\mathrm{FeOOH} \mathrm{O})+3 \mathrm{H}^{+}+2 e^{-} \leftrightarrow \mathrm{Fe}^{2+}+2 \mathrm{H}_{2} \mathrm{O}$ & $0-100$ \\
$\mathrm{SO}_{4}^{2-}+9 \mathrm{H}^{+}+8 e^{-} \leftrightarrow \mathrm{HS}^{-}+4 \mathrm{H}_{2} \mathrm{O}$ & $-200-0$ \\
$\mathrm{Methanogenesis}$ & $-300-0$ \\
\hline
\end{tabular}




\begin{tabular}{|c|c|c|c|c|c|c|c|c|}
\hline 苞 & 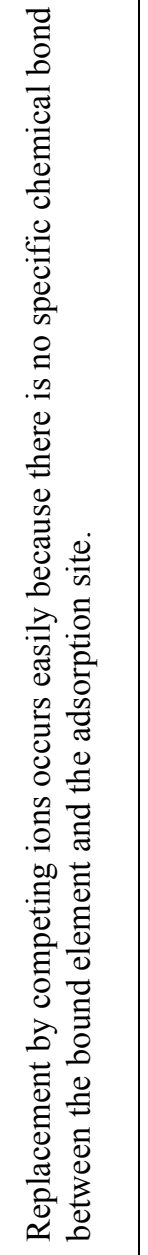 & 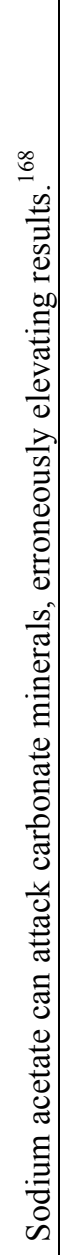 & 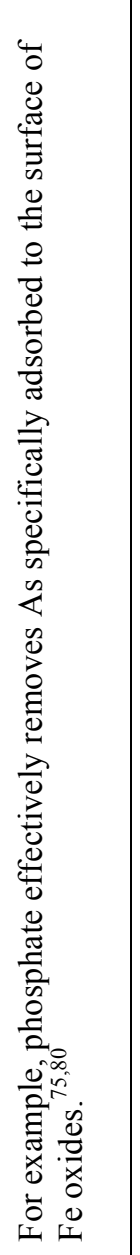 & 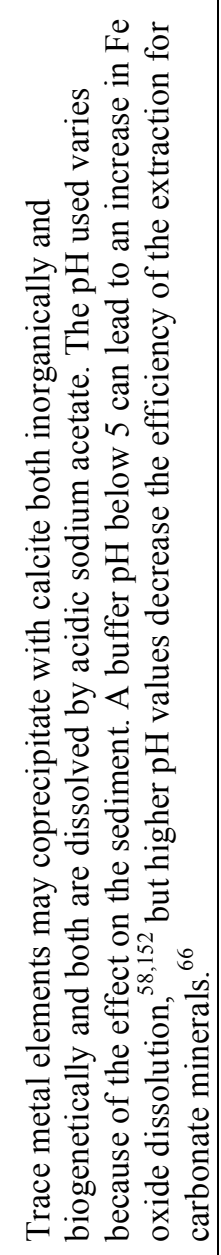 & 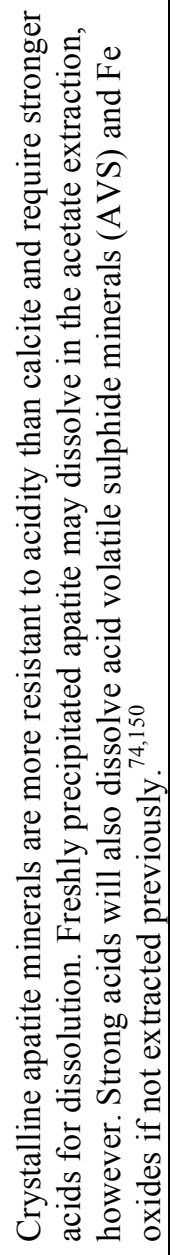 & 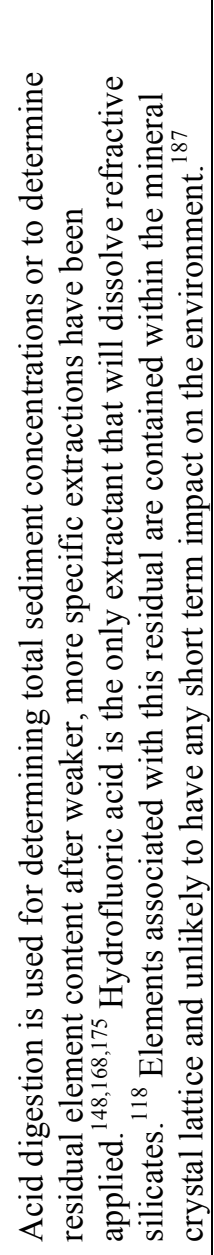 & 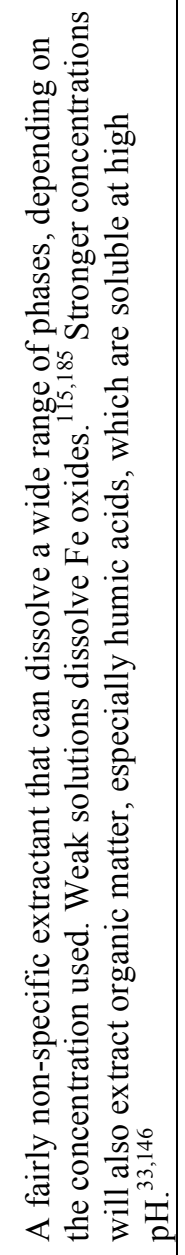 & 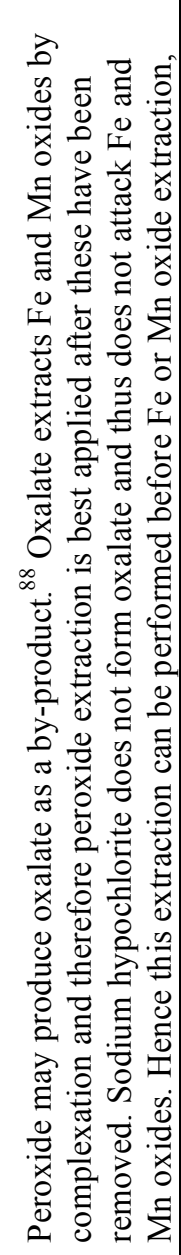 \\
\hline 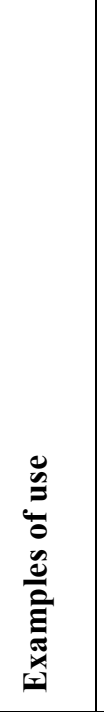 & 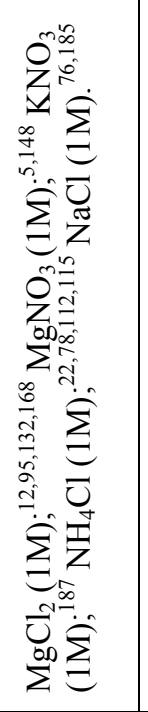 & 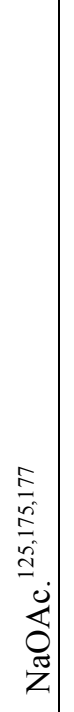 & 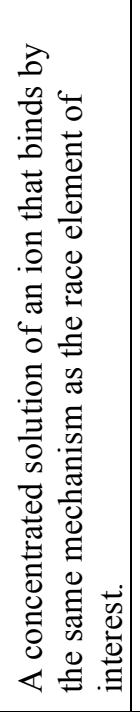 & 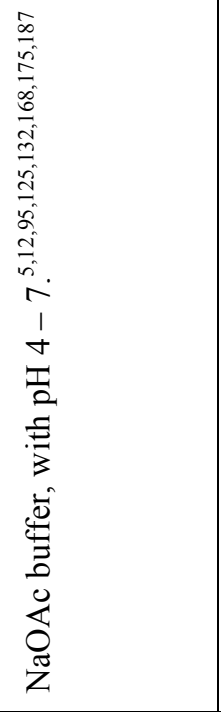 & 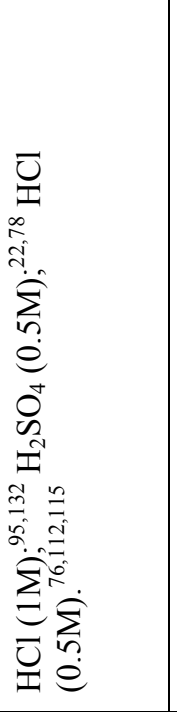 & 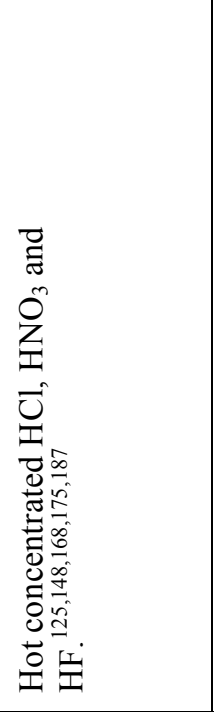 & 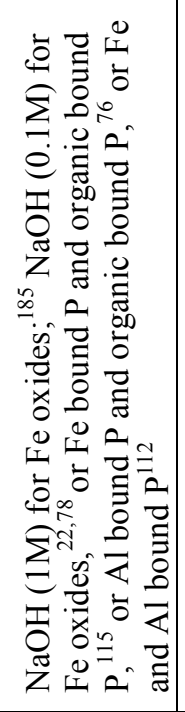 & 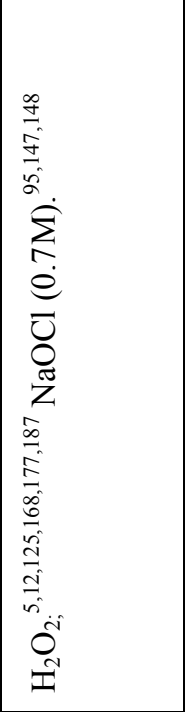 \\
\hline 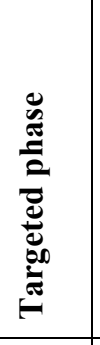 & 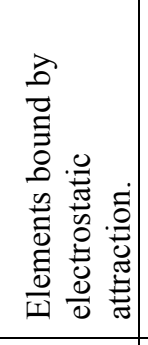 & & 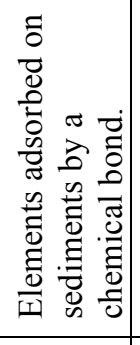 & 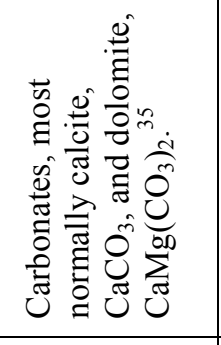 & 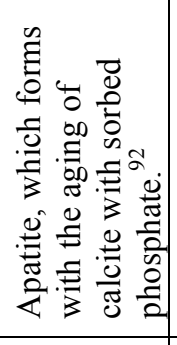 & 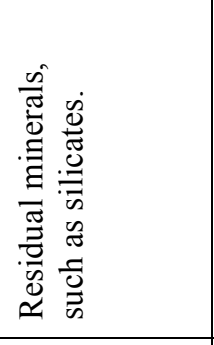 & 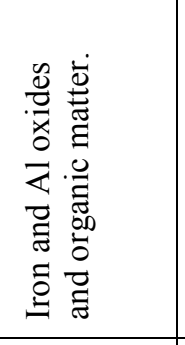 & 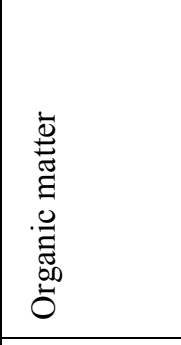 \\
\hline 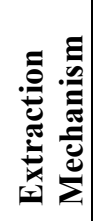 & 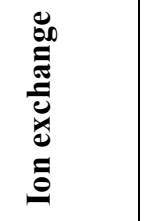 & & 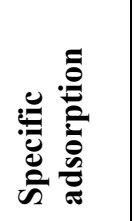 & 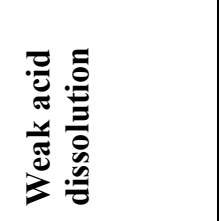 & 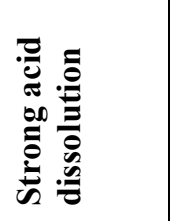 & & 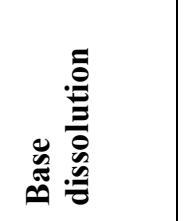 & \\
\hline
\end{tabular}




\begin{tabular}{|c|c|c|c|c|c|}
\hline 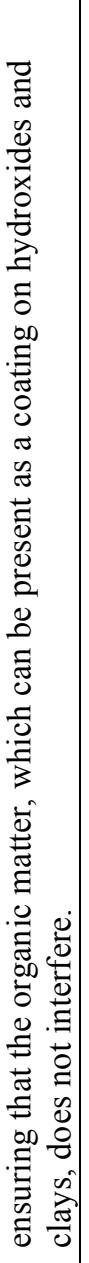 & 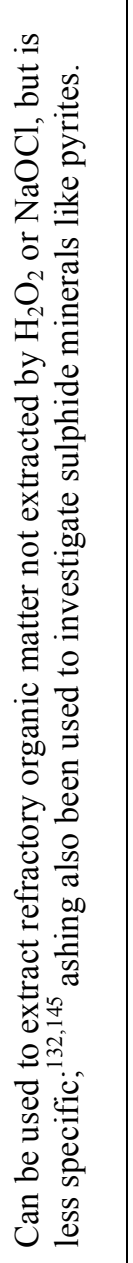 & 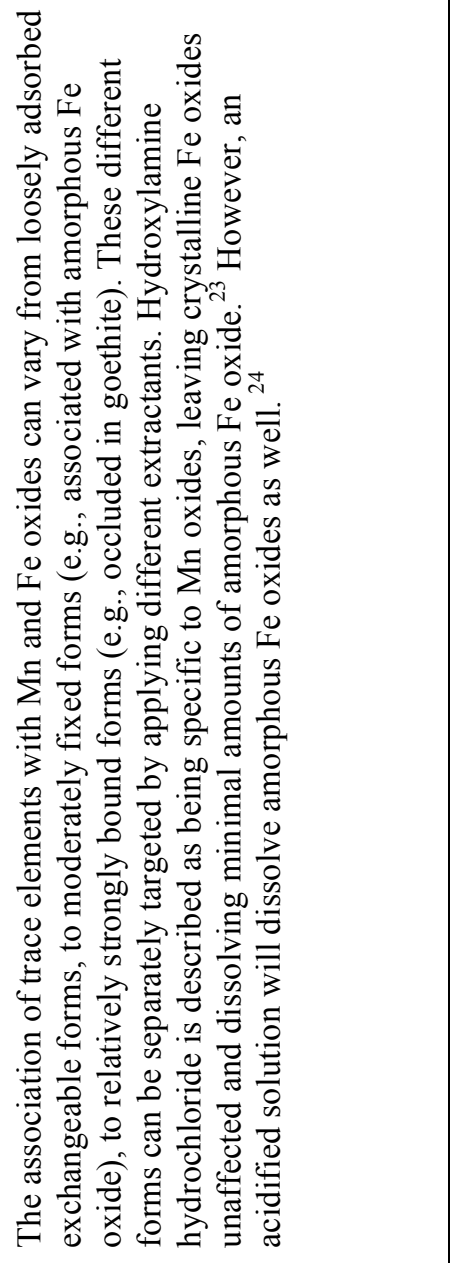 & 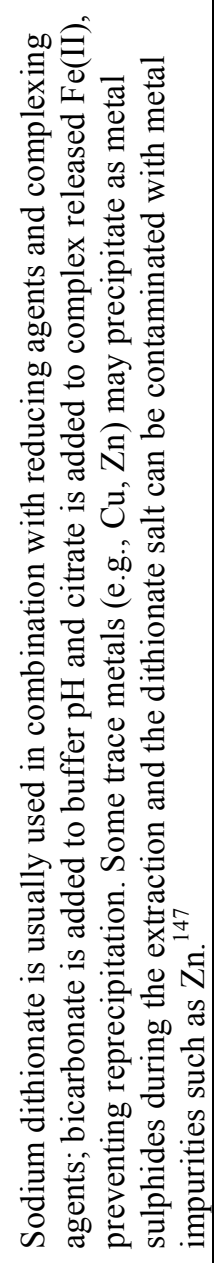 & 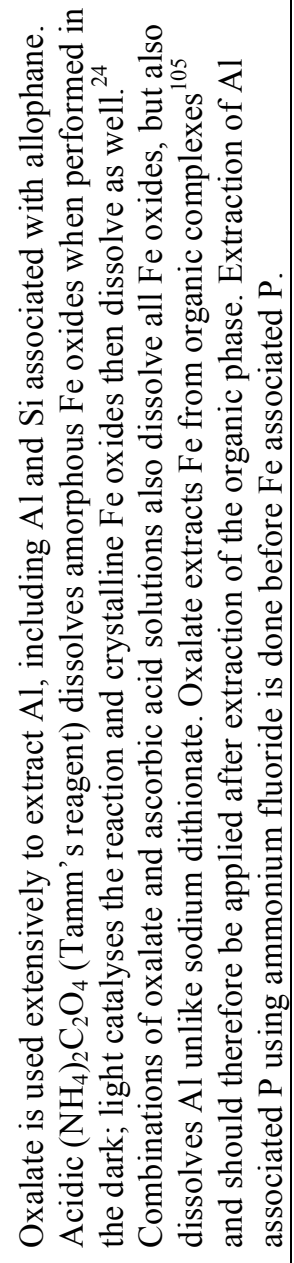 & 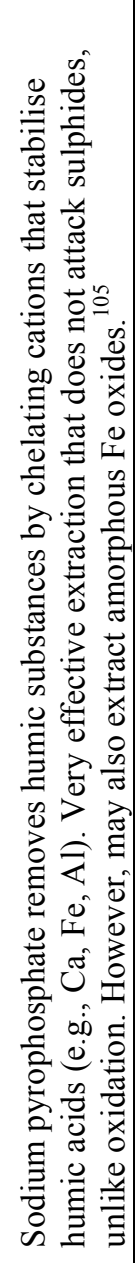 \\
\hline & 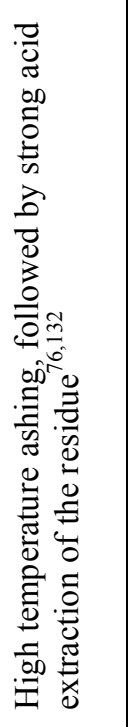 & 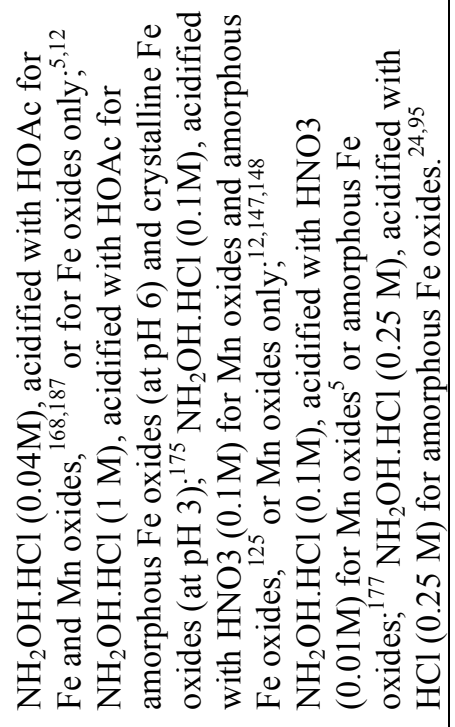 & 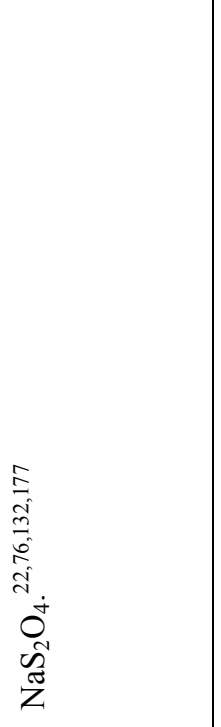 & 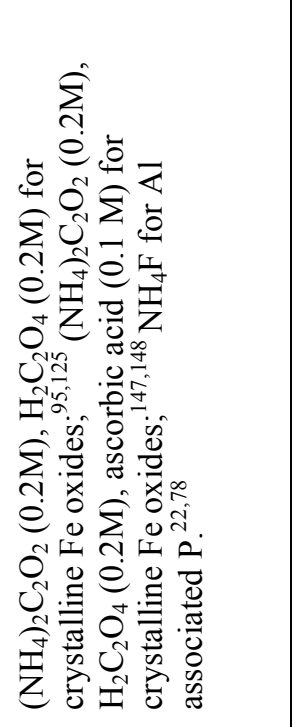 & 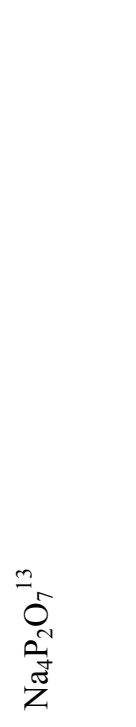 \\
\hline & 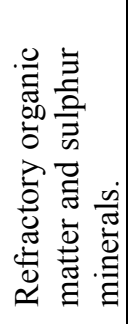 & 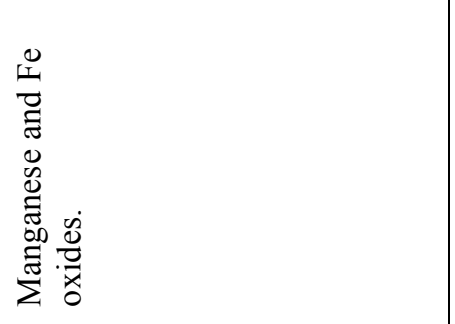 & 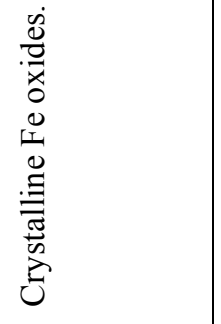 & 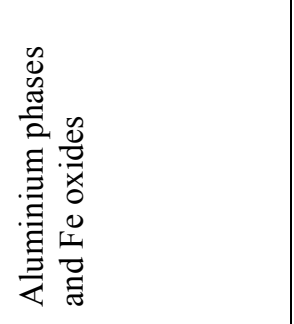 & 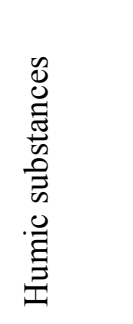 \\
\hline & & & & 宸 & \\
\hline
\end{tabular}


Table 3. Thermodynamic data at $25^{\circ} \mathrm{C} .-\Delta \mathrm{G}_{\mathrm{f}}{ }^{\mathrm{o}}$ is the standard free energy of formation, while $\mathrm{K}$ is the equation constant.

\begin{tabular}{|c|c|c|c|}
\hline Reaction & $\log K$ & $\begin{array}{l}-\Delta \mathrm{G}_{\mathrm{f}}{ }^{\mathrm{O}} \\
\text { (solid) }\end{array}$ & Reference \\
\hline $\mathrm{Fe}^{2+}+2 \mathrm{H}_{2} \mathrm{O} \leftrightarrow \mathrm{Fe}(\mathrm{OH})_{2}(s)+2 \mathrm{H}^{+}$ & -13.9 & 487 & 183 \\
\hline $\mathrm{Fe}^{3+}+2 \mathrm{H}_{2} \mathrm{O} \leftrightarrow \mathrm{FeOOH}(s)+3 \mathrm{H}^{+}$ & -41.7 & 490 & 183 \\
\hline $\mathrm{FeCO}_{3}(s) \leftrightarrow \mathrm{Fe}^{2+}+\mathrm{CO}_{3}^{2-}$ & -8.2 & 667 & 161 \\
\hline $\mathrm{CaCO}_{3}(s) \leftrightarrow \mathrm{Ca}^{2+}+\mathrm{CO}_{3}^{2-}$ & -8.5 & 1129 & 161 \\
\hline $\mathrm{Fe}_{3}\left(\mathrm{AsO}_{4}\right)_{2}(s) \leftrightarrow 3 \mathrm{Fe}^{2+}+2 \mathrm{AsO}_{4}^{3-}$ & -34.1 & 1766 & 183 \\
\hline $\mathrm{Fe}_{2} \mathrm{SiO}_{4}(s)+4 H^{+} \leftrightarrow 2 \mathrm{Fe}^{2+}+\mathrm{Si}(\mathrm{OH})_{4}$ & 3.7 & 1379 & 161 \\
\hline $\mathrm{Ca}_{10}\left(\mathrm{PO}_{4}\right)_{6}(\mathrm{OH})_{2}(s) \leftrightarrow 10 \mathrm{Ca}^{2+}+6 \mathrm{PO}_{4}^{3-}+2 \mathrm{OH}^{-}$ & -114 & 6338 & 161 \\
\hline $\mathrm{Fe}_{3}\left(\mathrm{PO}_{4}\right)_{2}(s) \leftrightarrow 3 \mathrm{Fe}^{2+}+2 \mathrm{PO}_{4}^{3-}$ & -26 & 2457 & 161 \\
\hline$F e S(s)+H^{+} \leftrightarrow F e^{2+}+H S^{-}$ & $-5(-3)$ & 100 & 161 \\
\hline $\mathrm{FeS}_{2}(s)+H^{+} \leftrightarrow \mathrm{Fe}^{2+}+H S^{-}+S$ & -14.2 & 160 & 161 \\
\hline
\end{tabular}


Table 4. Typical adsorption/desorption and precipitation/dissolution reactions.

\begin{tabular}{lll}
\hline & Typical Reaction & $\begin{array}{l}\text { Equilibrium } \\
\text { constant }\end{array}$ \\
\hline Adsorption/Desorption & $S-L_{(s)} \leftrightarrow S_{(s)}+L_{(a q)}$ & $K_{s}=\frac{[S][L]}{[S-L]}$ \\
Precipitation/Dissolution & $S L_{(s)} \leftrightarrow S_{(a q)}+L_{(a q)}$ & $K_{s p}=\frac{[S][L]}{[S L]}$
\end{tabular}


Table 5. Simple kinetic equations. ${ }^{7,50,123} \mathrm{C}$ is concentration at time t, $\mathrm{C}_{o}$ is initial concentration, $\mathrm{C}_{e}$ is equilibrium concentration, and $\mathrm{A}, \mathrm{b}, \mathrm{v}$, and $\mathrm{k}$ are constants.

\begin{tabular}{|c|c|c|c|}
\hline Number & Equation & Rate form & Integrated form \\
\hline 1 & Elovich & & $C=A+\frac{1}{b} \ln \left(t+t_{o}\right)$ \\
\hline 2 & Two constant rate equation & & $\ln C=\ln C_{o}+k \ln t$ \\
\hline 3 & Power Function/Freundlich & & $C=k t^{v}$ \\
\hline 4 & Zero order & $\frac{d C}{d t}=k$ & $C=k t$ \\
\hline 5 & Linear/First order & $\frac{d C}{d t}=k C$ & $\ln C=\ln C_{o}+k t$ \\
\hline 6 & Empirical First order & $\frac{d C}{d t}=k\left(C_{e}-C\right)$ & $\ln \left(\frac{C_{e}-C}{C_{e}-C_{o}}\right)=-k t$ \\
\hline 7 & Parabolic Diffusion Equation & $\frac{d C}{d t}=\frac{k}{2 \sqrt{t}}$ & $C=C_{o}+k \sqrt{t}$ \\
\hline
\end{tabular}

